\title{
Biochemical and Immunocytochemical Characterization and Distribution of Phosphorylated and Nonphosphorylated Subunits of Neurofilaments in Squid Giant Axon and Stellate Ganglion
}

\author{
Rochelle S. Cohen, ${ }^{1,4}$ Harish C. Pant, ${ }^{2,4}$ Shirley House, ${ }^{3}$ and Harold Gainer ${ }^{3,4}$ \\ 'Department of Anatomy, University of Illinois at Chicago, Chicago, IL 60612, '2Laboratory of Preclinical Studies, National \\ Institute on Alcohol Abuse and Alcoholism, Rockville, MD 20852, 'Laboratory of Neurochemistry and Neuroimmunology, \\ National Institute of Child Health and Human Development, Bcthesda, MD 20892, and ${ }^{4}$ The Marine Biological Laboratory, \\ Woods Hole, MA 02543
}

Monoclonal antibodies to squid neurofilament (aNFP) and intermediate filament (alFA) proteins were used as probes for the biochemical and immunocytochemical analyses of neurofilament structure and distribution in the squid giant axon and stellate ganglion. On Western blots the aNFP antibody stained exclusively the $220 \mathrm{kDa}$ and high-molecularweight (HMW) components of neurofilaments in the giant axon, whereas the alFA antibody primarily labeled the 60 kDa protein in the giant axon and the 60 and $65 \mathrm{kDa}$ proteins in the stellate ganglion. Dephosphorylation of axoplasmic proteins by alkaline phosphatase resulted in a decrease in the molecular weights of both the $220 \mathrm{kDa}$ and HMW neurofilament proteins and a concomitant loss of reactivity with the aNFP antibody on Western blots. This indicated that the aNFP antibody is specific for a phosphorylated epitope in the neurofilament. Increased dephosphorylation of the $\mathbf{2 2 0}$ kDa protein led to an enhanced immunostaining of the resultant $190 \mathrm{kDa}$ polypeptide by the alFA antibody, suggesting that the phosphorylated epitope may mask the conserved epitope recognized by alFA. Light and electron microscopic immunocytochemical studies show intense labeling by the aNFP antibody in the giant axon. In contrast, the alFA antibody labeled the glial cells around the giant axon intensely, while labeling of the giant axon itself was considerably less than that with the aNFP antibody. Since the $60 \mathrm{kDa}$ protein in axoplasm is intensely stained by the alFA antibody on Western blots, the relatively low amounts of labeling seen on semithin and thin sections of the giant axon by this antibody may be due to the masking of the 60 kDa proiein by in situ fixed axoplasmic proteins. However, the alFA antibody intensely labeled glial cells within the stellate ganglion and "islands" of filaments and nuclear membranes within ganglion cells. No reactivity for either antibody was seen in synapses. The aNFP antibody specifically labeled "beadlike" portions and cross-bridges on the axonal

\footnotetext{
Received May 20, 1986; revised Jan. 9, 1987; accepted Jan. 20, 1987.

We would like to acknowledge the excellent assistance of Mrs. Susan BoyleVavra and Mr. Al Cibavicius. We would also like to thank Dr. Michael Tytell for his help with some of the electrophoresis experiments. The electron microscope used in this study is located at the Electron Microscopy Facility of the University of Illinois at Chicago. This work was supported by NIH Grant NS 15889.

Correspondence should be addressed to Dr. Cohen, Department of Anatomy, University of Illinois at Chicago, 808 South Wood Street, Chicago, IL 60612.

Copyright (C) 1987 Society for Neuroscience $0270-6474 / 87 / 072056-19 \$ 02.00 / 0$
}

neurofilaments, suggesting that these components consist of the $220 \mathrm{kDa}$ and HMW proteins. In contrast, the alFA antibody labeled relatively smooth filaments in ganglion and glial cells. These data suggest that the $65 \mathrm{kDa}$ protein represents the squid glial filament protein and that the $60 \mathrm{kDa}$ protein found in axoplasm represents the low-molecularweight subunit in the axonal neurofilament. The latter appears to be formed and/or organized in "islands" of filaments within ganglion cells. These results support the view that the formation, maturation, and degradation of neurofilaments are regionally segregated within the neuron.

Neurofilaments are major components of the axonal cytoskeleton. Previous studies have indicated that neurofilament proteins isolated from the squid giant axon, as well as from other sources, appear to undergo posttranslational modifications by phosphorylation (Pant et al., 1978, 1979b; Eagles, 1981; Julien and Mushynski, 1981, 1982; Sternberger and Sternberger, 1983) and limited proteolysis by a calcium-activated protease (Gilbert et al., 1975; Pant et al., 1979a; Pant and Gainer, 1980; Schlaepfer and Zimmerman, 1985). In the squid axon, neurofilaments are composed of 2 major polypeptide subunits of 60 and $220 \mathrm{kDa}$, as well as a $>400 \mathrm{kDa}$ (HMW) protein (Pant et al., 1978; Lasek et al., 1979; Roslansky et al., 1980). As is the case for mammalian systems (Leterrier et al., 1981; Runge et al., 1981; Julien and Mushynski, 1982; Pierre et al., 1985), phosphorylation of the higher-molecular-weight forms of squid neurofilament proteins (i.e., 220 and $>400 \mathrm{kDa}$ ) occurs in axoplasm by the action of specific kinases (Pant et al., 1978, 1979b, 1986). In addition, a calcium-activated protease that selectively degrades neurofilament proteins has been demonstrated in squid axoplasm (Pant et al., 1979a, 1982; Pant and Gainer, 1980; Gallant et al., 1986).

Extensive light and electron microscopic studies of the intact giant axon and isolated neurofilaments prepared under several different conditions have provided a view of the characteristic structure of squid neurofilaments. In the intact axon, there appear to be differences in the density of neurofilaments. The greatest concentration is at the periphery, where they are arranged in bundles; here they are more parallel than in central regions (Metuzals and Izzard, 1969; Hodge and Adelman, 1980). A continuous 3-dimensional network in the giant axon, consisting of neurofilaments formed by intercoiled unit filaments with cross-bridge associations forming ladderlike patterns, has been described; squid neurofilaments also contain distinct 
"beadlike" portions along their length at regular intervals (Metuzals, 1969; Metuzals and Izzard, 1969; Hodge and Adelman, 1980, 1983; Rice et al., 1980; Roslansky et al., 1980; Metuzals et al., 1981a, b, 1982, 1983a, b; Villegas and Villegas, 1984).

In the present study, we make use of 2 monoclonal antibodies to determine the biochemical and morphological distribution of specific neurofilament proteins in the squid giant axon and stellate ganglion, and to correlate the state of phosphorylation of these polypeptides with their distribution and with specific neurofilament and neurofilament-associated structures. One of these antibodies (aNFP) specifically recognizes a phosphorylated epitope on the $220 \mathrm{kDa}$ and $\mathrm{HMW}$ proteins, whereas the other (aIFA) strongly cross-reacts with the conserved rod region of all intermediate filament proteins (aIFA) (Pruss et al., 1981; Cooper et al., 1984), including the $60 \mathrm{kDa}$ squid neurofilament protein. Recent advances in the use of colloidal gold-labeled secondary antibodies allow for the detailed localization of antibodies on resin-embedded tissue sections (Bendayan, 1983; Cohen et al., 1985). Using these techniques, we have explored the general distribution of the $220 \mathrm{kDa}$ subunit of neurofilament protein and $60 \mathrm{kDa}$ subunit of intermediate filament protein within and around the giant axon and within the stellate ganglion of the squid by light and electron microscopic immunocytochemistry. We have also cxamined the localc of these subunits on neurofilaments and associated structures and on intermediate filaments. The morphological results are compared to biochemical data obtained on the distribution of these polypeptides using Western blots. In order to determine further whether the antibodies are specific for the phosphorylated epitopes on the polypeptides, dephosphorylation of neurofilaments with alkaline phosphatase was performed, and the resultant polypeptides were analyzed for immunoreactivity with the monoclonal antibodies on Western blots. In this way, we were able to correlate the phosphorylation states of the neurofilament subunits with their cellular distributions in the cell bodies and axons of the squid giant axon system.

\section{Materials and Methods}

\section{Biochemical studies}

Isolation of axoplasm and stellate ganglion cell bodies. Axoplasm was isolated from squid giant axons of live squid (Loligo pealei) obtained at the Marine Biological Laboratory, Woods Hole, MA. The animals were maintained for a few hours in laboratory tanks containing running seawater before use. Dissection of the dorsal giant nerve fiber was performed under running seawater on a dissecting table illuminated from below through a glass window. These axons were about $60 \mathrm{~mm}$ in length and $400-600 \mu \mathrm{m}$ in diameter. For convenience in subsequent manipulations, each end of the axon was ligated with thread prior to excision. Dark-field illumination and a dissecting microscope were used for extensive cleaning of the axon. The cleaned axons were rinsed in ice-cold isosmolar sucrose to remove the external seawater and blotted, and the axoplasm was extruded from the intact living axon in the conventional manner (Lasek, 1974) so as to avoid contamination of the axoplasm by seawater. Extruded axoplasm was quickly transferred into eppendorf tubes on ice containing either a $5 \mathrm{~mm}$ EDTA, $40 \mathrm{~mm}$ Tris, $1 \mathrm{mg} / \mathrm{ml}$ leupeptin, pH 7.0 solution or a $1 \mathrm{~mm}$ EGTA, $10 \mathrm{~mm} \mathrm{MgCl}_{2}, 100 \mathrm{~mm}$ $\mathrm{NaCl}, 20 \mathrm{~mm}$ HEPES, $50 \%$ glyccrol, pH 7.0 solution, and frozen for further use. The stellate ganglia were dissected in running seawater and rinsed briefly in ice-cold isosmolar sucrose; the cell body-containing region of the ganglion was excised, immediately homogenized in SDSgel homogenizing buffer ( $2 \% \mathrm{SDS}, 5 \% 2-\beta$-mercaptoethanol), and stored frozen at $-20^{\circ} \mathrm{C}$.

SDS-PAGE and Western blots. SDS-PAGE of squid tissue proteins was performed according to the methods of Nevelle (1971). Stacking gels were $4 \%$ acrylamide, and running gels were $7.5 \%$ acrylamide. The molecular weight standards used were: rabbit skeletal muscle myosin (212 kDa), Escherichia coli B-galactosidase (135 kDa), phosphorylase
$(90 \mathrm{kDa})$, BSA $(68 \mathrm{kDa})$, pyruvate kinase $(57 \mathrm{kDa})$, and ovalbumin $(43$ $\mathrm{kDa}$. Gels were stained with $1.0 \%$ Coomassie brilliant blue R (Bio Rad) in $7 \%$ acetic acid, $35 \%$ methanol for $12 \mathrm{hr}$, and destained in several changes of $7 \%$ acetic acid, $35 \%$ methanol. In cases where the tissue proteins were TCA precipitated (see below), all samples for SDS-PAGE were prepared as follows: SDS, $2 \%$, was added to the TCA washed and acetone dried pellets, and the solution was heated at $100^{\circ} \mathrm{C}$ for $1 \mathrm{~min}$. The sample was then reduced by adding $2 \%$ (by volume) $2-\beta$-mercaptoethanol, in upper gel buffer $\left(220 \mathrm{~mm}\right.$ Tris- $\mathrm{HCl}$ and $0.1 \mathrm{~N} \mathrm{H}_{2} \mathrm{SO}_{4}, \mathrm{pH}$ 6.1 ). Bromophenol blue $(1 \%)$ was used as a tracking dye. Aliquots of $50-100 \mu \mathrm{l}(50-100 \mu \mathrm{g}$ protein) samples were used for SDS-PAGE. Western blots were performed after electrophoretic transfer of proteins from the $7.5 \%$ acrylamide gel onto nitrocellulose paper. Transfer was carried out in a Hoefer Transphore unit for $15-18 \mathrm{hr}$ at $15^{\circ} \mathrm{C}, 60 \mathrm{~V}, 1000-2000$ milliamps. The paper was then removed, blocked with $10 \%$ fetal calf serum in PBS for $18 \mathrm{hr}$, and then exposed overnight to 1:5 dilutions of culture supernatants containing either aNFP or aIFA (see below) in $10 \%$ fetal calf scrum, PBS. Following 10-12 washcs in PBS, the second antibody, a 1:300 dilution of peroxidase labeled goat anti-mouse antibody (Boehringer Mannheim) in PBS, was applied for $2 \mathrm{hr}$. The paper was then washed in Tris buffered saline ( $20 \mathrm{~mm}$ Tris, $0.9 \% \mathrm{NaCl}, \mathrm{pH} 7.2)$, $16 \mathrm{ml} \mathrm{4-chloro-1-napthol}(3 \mathrm{mg} / \mathrm{ml}$ in methanol), and $32 \mu \mathrm{l}$ of fresh $30 \% \mathrm{H}_{2} \mathrm{O}_{2}$.

Dephosphorylation of squid axoplasm proteins. Extruded squid axoplasm (see above) was extensively dialyzed at $4^{\circ} \mathrm{C}$ against dephosphorylation buffer ( $50 \mathrm{~mm}$ Tris, $100 \mathrm{mM} \mathrm{NaCl}, 1 \mathrm{~mm} \mathrm{ZnSO}$, pH 8.0) containing $1 \mathrm{~mm}$ PMSF (Sigma) and $0.1 \mathrm{mg} / \mathrm{ml}$ each of leupeptin, pepstatin $A$, antipain, and bestatin (Peninsula Labs) to inhibit proteolysis. Various concentrations of $E$. coli alkaline phosphatase (type III R, Sigma) were added to $200 \mu \mathrm{g}$ of axoplasm proteins in the above dephosphorylation buffer and incubated for $5 \mathrm{hr}$ at $37^{\circ} \mathrm{C}$. The reactions were terminated by prccipitation in $10 \%$ TCA, and the TCA precipitates were prepared for SDS-PAGE and Western blots as described above.

\section{Monoclonal antibodies to squid neurofilaments}

Mouse monoclonal antibodies to squid axoplasm were prepared using conventional hybridoma procedures used in our laboratory (Ben-Barak et al., 1985). The immunogen used to immunize BALB/c mice was glutaraldehyde-fixed extruded squid axoplasm, and the spleens of 3 mice showing high serum titers against axoplasm in enzyme-linked immunosorbent assay (ELISA) were used for fusion. Using ELISA and Western blot assays, we were able to obtain 5 distinct hybridoma clones that secreted antibodies that specifically reacted with the $220 \mathrm{kDa}$ and HMW neurofilament proteins in squid axoplasm. One of these, clone 4D5C6(C8), which we designated aNFP, was exclusively used in this study (see Fig. 1 for Western blot stain using aNFP on axoplasm). Ouchterlony double-diffusion analysis showed that aNFP was an IgM. The anti-intermediate filament antibody (aIFA) was obtained from culture supernatants of the alFA hybridoma, ATCC T1B131 (American Type Culture Collection, Rockville, MD). This antibody is an $\mathrm{IgG}_{1}$ and cross-reacts with the conserved $\alpha$-helical rod region in virtually all intermediate filaments (Pruss et al., 1981; Cooper et al., 1984), including the $60 \mathrm{kDa}$ neurofilament protein in axoplasm (Fig. 1).

\section{Immunocytochemical studies}

Fixation and embedding. Intact squid giant axons and stellate ganglia were dissected as described above and immediately immersed in $1 \%$ glutaraldehyde, $4 \%$ paraformaldehyde in calcium-free artificial seawater, $\mathrm{pH}$ 7.3-7.4. The giant axon was then cut into smaller pieces, and the stellate ganglion was subdivided further into areas containing predominantly ganglion cells or synapses. The pieces of tissue remained in the fixative overnight; the following day they were transferred to $0.1 \mathrm{M}$

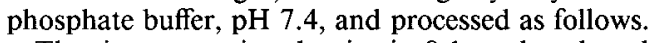

The tissuc was rinsed twice in $0.1 \mathrm{M}$ phosphate buffer, $\mathrm{pH} 7.4$, and then dehydrated and embedded in LR White (medium grade, Ernest F. Fullam, Inc., Latham, NY) according to previously published methods (Cohen et al., 1985). Since LR White is sensitive to oxygen, gelatin capsules were used as embedding molds. In order to obtain longitudinal sections of the squid giant axon, the pieces were embedded according to the technique of Ridgway et al. (1984). Disks made of hole punches of developed electron microscopy film were used as platforms for orienting the tissue. A tab for handling the disks with forceps was made by making 2 slits in the disk. The giant axon was then oriented horizontally in a drop of LR White placed on the disk. After a few drops 


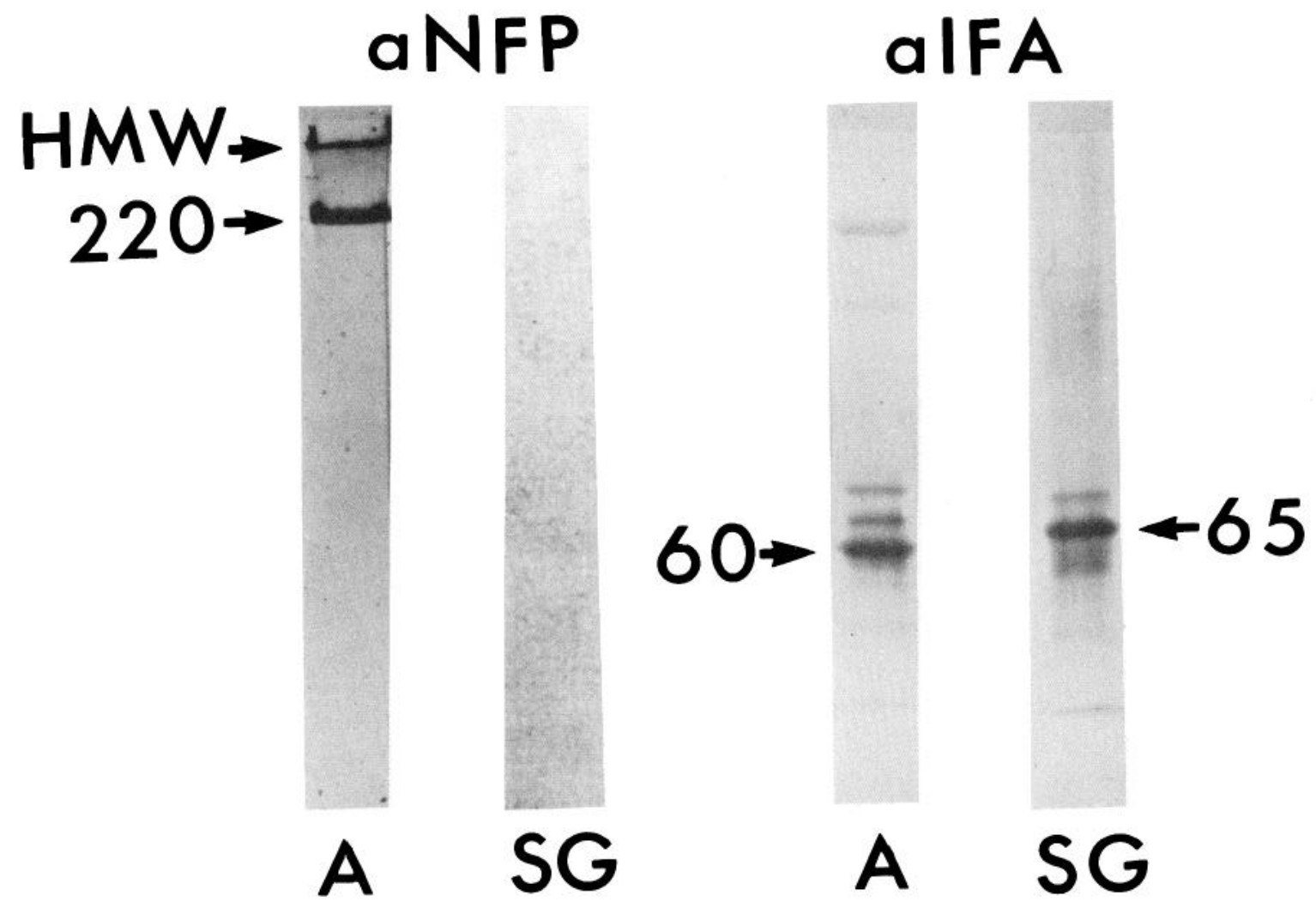

Figure 1. Western blots, using aNFP and aIFA, of squid axoplasm $(A)$ and stellate ganglion cell body $(S G)$ proteins. Note that the aNFP monoclonal antibody stained only the HMW and $220 \mathrm{kDa}$ proteins in axoplasm $(A)$ and showed virtually no staining in the stellate ganglion $(G)$. The aIFA monoclonal antibody stained a number of proteins in axoplasm, the major band being the $60 \mathrm{kDa}$ neurofilament protein (note the light band in SG corresponding to the $190 \mathrm{kDa}$ protein in Fig. 3). In the SG sample, the aIFA intensely stained a $65 \mathrm{kDa}$ band and exhibited a number of moderately stained bands, including a $60 \mathrm{kDa}$ band.

of LR White were added to a predried gelatin capsule, the disk was gently placed in the capsule on top of the added resin. LR White was then added to the rest of the capsule, which was then covered with the top of the capsule to limit exposure to air. All capsules were polymerized overnight at $60^{\circ} \mathrm{F}$.

\section{Light microscopic immunocytochemistry}

The immunocytochemical localization of the aNFP and aIFA monoclonal antibodies was performed on semithin $(0.5-1.0 \mu \mathrm{m})$ sections of LR White embedded giant axon and stellate ganglion. Colloidal gold ( 5 $\mathrm{nm}$ ) was used as a probe, which was visualized by silver enhancement. In order to improve adhesion of the section onto the slide, the glass slides were individually wiped clean using ethanol-soaked optical lens tissue and placed in a slide staining rack. The rack was then dipped in a cooled $0.1 \%$ gelatin solution for $\sim 10 \mathrm{sec}$ and allowed to dry at either room temperature or in a mildly warm oven. Frosted slides were used to facilitate differentiating both sides of the slide. Semithin $(0.5-1.0 \mu \mathrm{m})$ sections were cut from each block and placed in drops of water on the slide. The slides were then permitted to dry on a hot plate. The use of separate slides for each antibody eliminated the possibility of crosscontamination.

Slides were placed on top of a grid box (or other platform) in a square Petri dish lined with a moist paper towel for all of the following immunocytochemical steps (except rinsing):

1. On a dry slide 200-300 $\mu$ l of BSA (Grade V, Sigma Chemical Co., St. Louis, MO) were used to cover each group of sections, which were then incubated for $30 \mathrm{~min}$ at room temperature. The slides were then drained by permitting the drops of BSA to drip onto a paper towel. In order to prevent spreading in the next step, the areas around the sections were carefully wiped with a Kimwipe or filter paper.

2. The sections were then incubated with $50-100 \mu \mathrm{l}$ of $5 \%$ normal goat serum (NGS) (Sternberger-Meyer Immunochemicals, Inc., Jarretsville, MD) in Tris-buffered saline (TBS) $+0.1 \%$ BSA (TBS-BSA) for $30 \mathrm{~min}$ at room temperature.
3. The sections were incubated with the aNFP (diluted 1:2) or aIFA (diluted 1:5) monoclonal antibodies or 1\% NGS in TBS-BSA buffer as a control, overnight at $4^{\circ} \mathrm{C}$.

4. The following day, the slides treated with the different antibodies were rinsed with TBS-BSA in separate Coplin jars placed on a shaker 3 times for $10 \mathrm{~min}$ each. After rinsing, the slides were wiped around the sections as described above and then returned to Petri dishes containing moist paper towels.

5 . The sections were then incubated with $50-100 \mu \mathrm{l}$ of secondary antibodies labeled with $5 \mathrm{~nm}$ colloidal gold (goat anti-mouse IgG; Janssen Pharmaceutica, Piscataway, NJ), diluted to $\sim 1: 3$, for $3 \mathrm{hr}$ at room temperature.

6 . The slides were then rinsed 3 times for $10 \mathrm{~min}$ each and drained as described above.

7. The slides were washed twice for 5 min each with PBS (pH 7.2).

8 . The sections were then postfixed in $2 \%$ glutaraldehyde in PBS buffer for $\sim 5 \mathrm{~min}$ in order to prevent bleaching of the antibodies during subsequent harsh acid developing during the silver enhancement procedure.

9. The slides were then rinsed twice for 3 min each in PBS and then rinsed 3 times for $3 \mathrm{~min}$ in water or $6 \mathrm{~min}$ of continuous washing in distilled/deionized water.

The silver enhancement procedure was performed according to the instructions in the Janssen Silver Enhancement Kit (Janssen Pharmaceutica, Piscataway, NJ) (De Mey, 1984). Since the preparation of this manuscript, Janssen Pharmaceutica has issued a new kit, "IntenSE," that is light-insensitive. The following procedure, however, is based on instructions in the original kit. The procedure was carried out in the dark. The chemicals were weighed with the room lights out and placed in aluminum foil-covered glassware, as they are light-sensitive. All solutions were made fresh. The silver enhancement procedure is as follows.

1. Slides were placed in a prewash solution $(20 \mathrm{ml}$ citrate stock, made by dissolving $11.75 \mathrm{~g}$ trinatrium citrate $2 \mathrm{H}_{2} \mathrm{O}$ and $12.75 \mathrm{~g}$ citric acid $\mathrm{H}_{2} \mathrm{O}$ in $50 \mathrm{ml}$ distilled/deionized water, and $180 \mathrm{ml}$ distilled/deionized water) for $2 \mathrm{~min}$. 


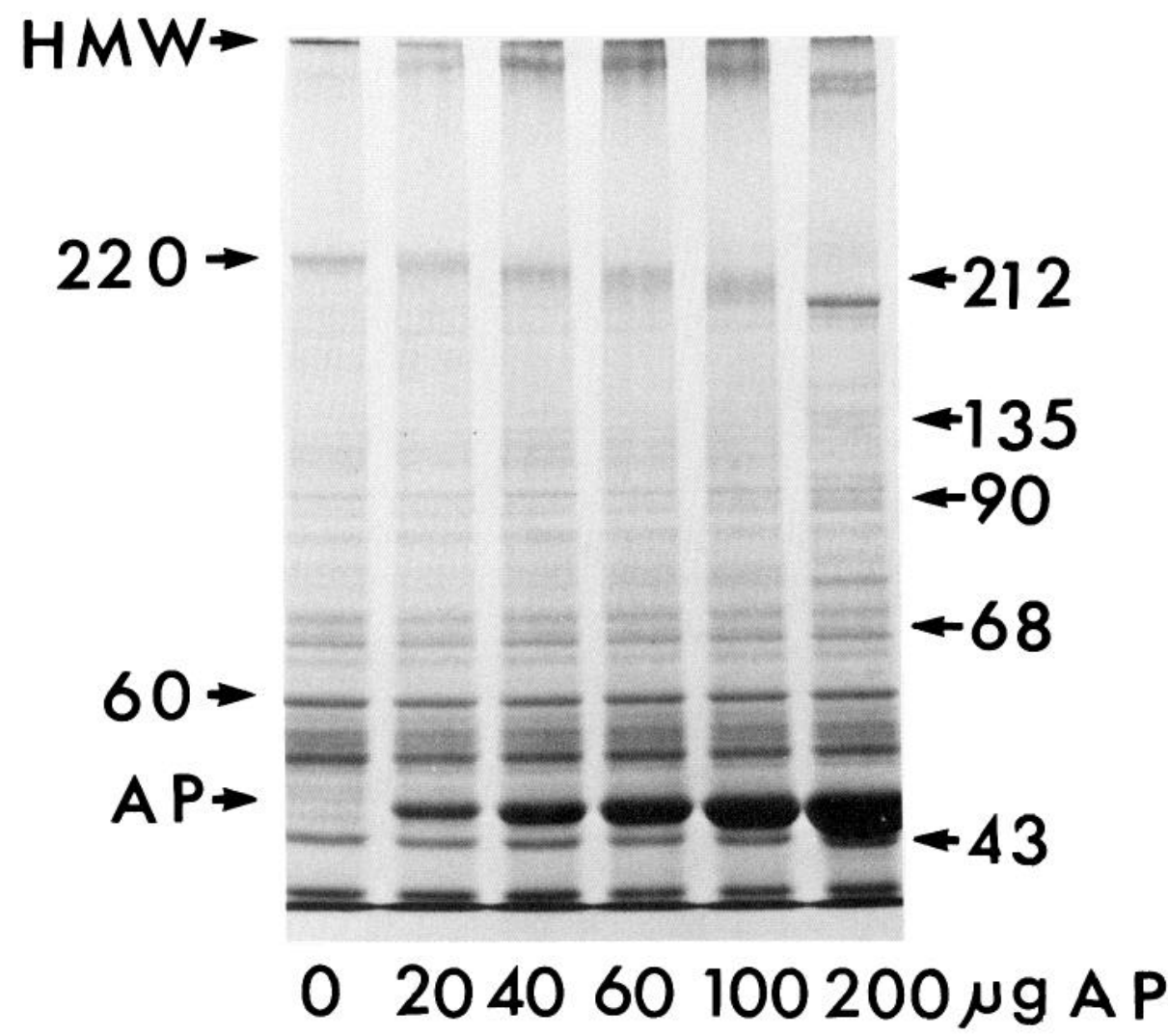

Figure 2. Effect of alkaline phosphatase $(A P)$ on the separation of proteins in squid axoplasm by $7.5 \%$ SDS-PAGE. Squid axoplasm, $200 \mu \mathrm{g}$, was incubated for $5 \mathrm{hr}, 37^{\circ} \mathrm{C}$, with various concentrations of alkaline phosphatase $(A P)$ and subsequently electrophoresed; the gel was stained with Coomassie blue (see Materials and Methods). The concentration of AP used in the incubation is shown beneath each lane. The control lane (incubated without AP, i.e., $0 \mu \mathrm{g}$ AP) is shown at left. Migration positions of various forms of neurofilament proteins (HMW, $220 \mathrm{kDa}$, and $60 \mathrm{kDa}$ ), as well as the added AP, are also shown at left. Note that the major changes in migration position as a result of AP action were for the HMW and $220 \mathrm{kDa}$ neurofilament proteins and that there was a gradual broadening of the $220 \mathrm{kD}$ protein with increasing AP concentrations until a final sharp band (about 190 $\mathrm{kDa}$ ) was obtained at $200 \mu \mathrm{g} \mathrm{AP}$.

2. While slides were in the prewash solution, the developer was made by pouring the hydroquinone solution $(0.85 \mathrm{~g}$ hydroquinone in $15 \mathrm{ml}$ distilled/deionized water) and the silver lactate solution $(0.11 \mathrm{~g}$ silver lactate in $15 \mathrm{ml}$ distilled/deionized water) into a second citrate solution $(10 \mathrm{ml}$ of citrate stock as described above in $60 \mathrm{ml}$ distilled/deionized water). The resultant solution was shaken. It should be noted that the silver lactate and hydroquinone are not mixed together until moments before use, and this is done under a safelight.

3 . The developer was poured into empty Coplin jars. The slides were placed in the Coplin jars containing the developer for 4-6 min at about $27^{\circ} \mathrm{C}$.

4. The slides were transferred to a fixing solution $(10 \mathrm{ml}$ fixer in 90 $\mathrm{ml}$ distilled/deionized water) for no longer than $2 \mathrm{~min}$.

5 . The slides were transferred to distilled/deionized water and rinsed for $30 \mathrm{~min}$ in or out of the light. The control for the silver enhancement procedure involved incubating the silver enhancement chemicals on unlabeled tissue to see if there was any nonspecific development of the section.

Some sections were not processed for immunocytochemistry and, instead, were stained with $0.1 \%$ toluidine blue. After coverslips were placed on all slides, the sections were viewed with a bright- or darkfield condenser. The latter increases the contrast of the silver-enhanced colloidal gold particles. The sections were photographed with a Zeiss and Olympus $\mathrm{BH} 2$ photomicroscope.

\section{Electron microscopic immunocytochemistry}

The immunocytochemical localization of the aNFP and aIFA monoclonal antibodies on thin sections of the squid giant axon and stellate ganglion using colloidal gold as a probe was performed according to previously published methods (Cohen et al., 1985) with minor modifications. These include the use of uncoated (i.e., no Formvar coat) nickel and/or gold grids. Since the antibody labels only those epitopes at the surface of the section, the use of uncoated grids doubles the number of sites available for labeling. The dilutions of the antibodies were the same as those described above for light microscopic immunocytochemistry.

The control involved incubating some sections with $1 \%$ NGS in TBSBSA buffer. Both the aNFP and aIFA monoclonal antibodies also served as complementary controls for each other.

\section{Technical considerations}

The light microscopic immunocytochemical study presented here indicates that the silver enhancement of colloidal gold particles can be used on resin-embedded tissue labeled with primary antibodies and secondary antibodies labeled with colloidal gold. In the present study, the tissue was embedded in LR White, which has previously been shown to be useful for electron microscopic postembedding immunocytochemistry using biotin-streptavidin (Whitnall et al., 1983) and colloidal gold (Craig and Miller, 1984; Cohen et al., 1985) as probes. The silver enhancement technique can also be used with semithin Epon (Danscher and Norgard, 1983) and de-embedded (J. Wolosewick, personal communication) sections. Use of this technique on semithin resin embedded tissues is advantageous for the following reasons: (1) the improved resolution of the tissue over thicker vibratome or cryostat sections, (2) the improved resolution of the probe itself over fluorescent- or peroxidaselabeled secondary antibodies, (3) the ability to use the same block for light and electron microscopic immunocytochemistry when colloidal gold is used as a probe, (4) the quantitative view of the amount of immunoreactivity, (5) the stability of silver-enhanced gold particles over time, and (6) the possibility of counterstaining the sections (Danscher, 1981; Roth, 1982; Holgate et al., 1983; De Mey, 1984; Springall et al., 1984). Also, the immunocytochemical results obtained with the silver enhancement technique can be viewed directly with bright-field microscopy, although a dark-field condenser was used to improve contrast in the present study.

\section{Results}

\section{Western blot analysis and dephosphorylation studies}

Analysis of the immunoreactivity of the aNFP and aIFA antibodies to proteins in the squid giant axon and stellate ganglion is illustrated in the Western blots in Figure 1. The Coomassie blue staining pattern of proteins in the axoplasm is shown in lane 1 of Figure 2. The major neurofilament proteins include the 60 and $220 \mathrm{kDa}$ and HMW proteins. In axoplasm, the aNFP monoclonal antibody stained only the $220 \mathrm{kDa}$ and HMW pro- 


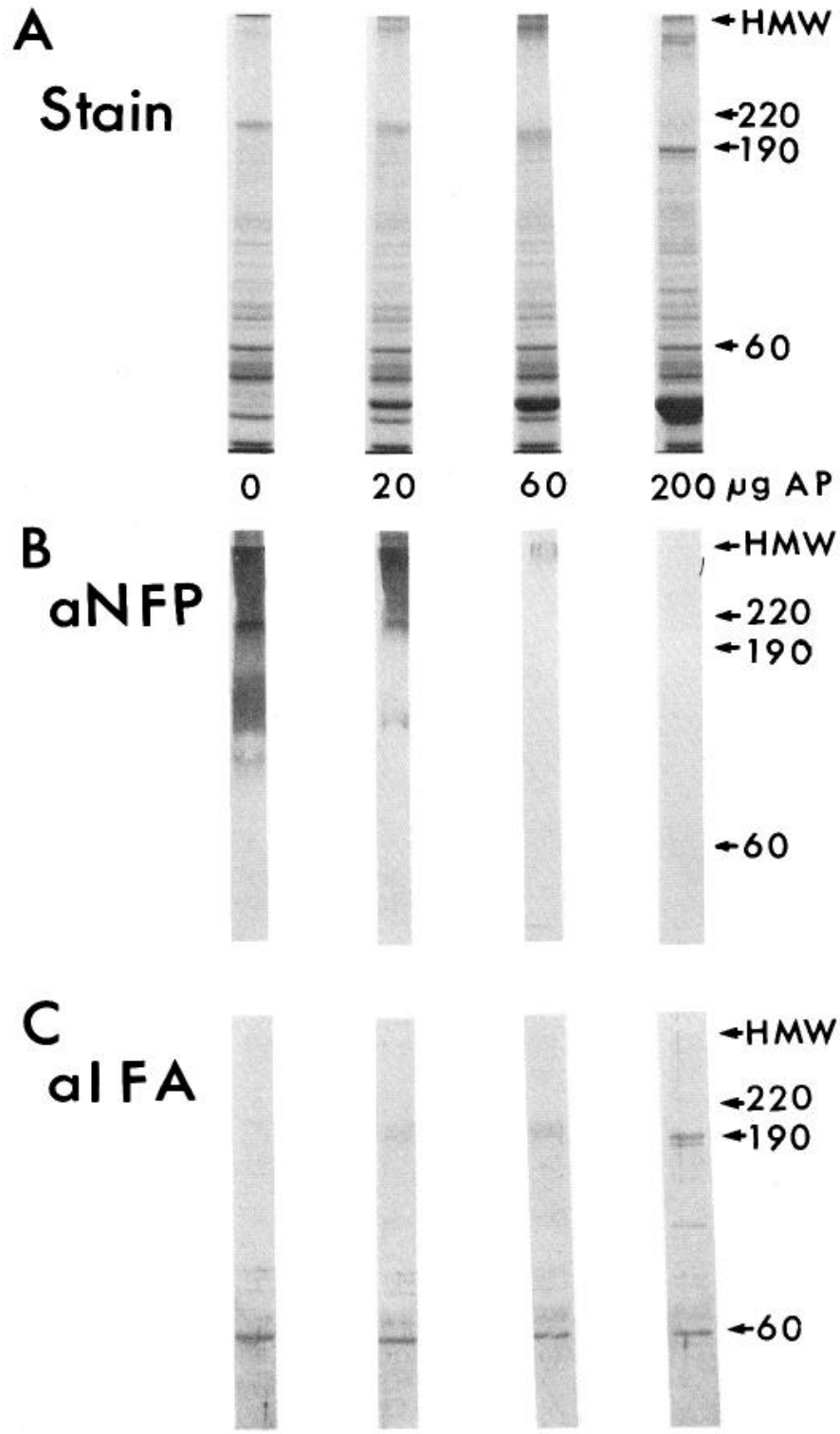

Figure 3. Western blots of squid axoplasm using aNFP monoclonal antibody $(B)$ and aIFA $(C)$ monoclonal antibody at various conditions of dephosphorylation by AP (see Fig. 1). A, Coomassie blue stain of axoplasmic proteins separated by SDS-PAGE. $B$ and $C$, Corresponding Western blot stains of samples shown in $A$. Note that immunostaining by the aNFP antibody $(B)$ is completely eliminated by the $60 \mu \mathrm{g}$ AP incubation, indicating that this antibody is recognizing a phosphorylated epitope. The overstaining in this series (e.g., at $0 \mu \mathrm{g} \mathrm{AP}$ ) was due to use of a high concentration of antibody (i.e., undiluted culture supernatant) in order to be certain that the loss of staining was not due to low antibody titer. A more typical staining of axoplasm using aNFP (at a 1:5 dilution of culture supernatant) is shown in Figure 1 (first lane). In contrast to the above results, the efficacy of staining by aIFA was enhanced by increasing dephosphorylation $(C)$. Note that upon presumed complete dephosphorylation $(200 \mu \mathrm{g} \mathrm{AP})$ the $190 \mathrm{kDa}$ protein was as intensely stained, whereas the $60 \mathrm{kDa}$ neurofilament proteins' intensity of staining was unaffected by AP treatment.

teins; no staining in the stellate ganglion was detected using this antibody. In contrast, the aIFA antibody intensely stained the $60 \mathrm{kDa}$ protein in axoplasm, as well as a number of other proteins. In the stellate ganglion, however, the aIFA antibody intensely stained a $65 \mathrm{kDa}$ protein and moderately stained some others, including one at $60 \mathrm{kDa}$.
Treatment of axoplasm by alkaline phosphatase had a marked effect on the mobilities of the $220 \mathrm{kDa}$ and $\mathrm{HMW}$ proteins in the giant axon (Fig. 2). Incubation of axoplasm $(200 \mu \mathrm{g})$ with increasing concentrations $(0-200 \mu \mathrm{g})$ of alkaline phosphatase resulted in an increased mobility on the SDS gel of the $220 \mathrm{kDa}$ and HMW proteins. The $220 \mathrm{kDa}$ band showed a gradual broadening with increasing alkaline phosphatase concentrations until a final sharp band at $190 \mathrm{kDa}$ was visible with $200 \mu \mathrm{g}$ of alkaline phosphatase. The immunochemical analysis of squid axoplasm using the aNFP and aIFA monoclonal antibodies at various conditions of dephosphorylation is shown in Figure 3. While the aNFP antibody intensely stains the $220 \mathrm{kDa}$ and HMW proteins with no alkaline phosphatase treatment, there is a marked decrease in staining with incubation of $20 \mu \mathrm{g}$ of alkaline phosphatase and a complete loss of staining at $>60 \mu \mathrm{g}$ alkaline phosphatase (Fig. $3 B$ ). In contrast, increasing concentrations of alkaline phosphatase resulted in an enhancement of staining of the dephosphorylated forms of the $220 \mathrm{kDa}$ protein by the aIFA antibody (Fig. 3C). When the $220 \mathrm{kDa}$ protein was presumed to be completely dephosphorylated (200 $\mu \mathrm{g}$ alkaline phosphatase) to yield the $190 \mathrm{kDa}$ band (Fig. $3 \mathrm{~A}$ ), the aIFA antibody stained the $190 \mathrm{kDa}$ band as intensely as the $60 \mathrm{kDa}$ protein, which was unaffected by alkaline phosphatase treatment (Fig. $3 C$ ).

\section{Light microscopic immunocytochemistry}

Giant axon. In order to assess the relative amounts of labeling of the aNFP and aIFA monoclonal antibodies in the squid giant axon and stellate ganglion, light microscopic immunocytochemistry was performed using silver-enhanced colloidal gold as a probe on semithin sections of LR White. Figure 4 shows the results of labeling of the giant axon with aNFP and aIFA antibodies using this technique. A toluidine blue-stained semithin section of a tangential view of the giant axon is seen in Figure $4 a$. The giant axon is surrounded by a thin glial cell, which is, in turn, surrounded by connective tissue containing fibrocytes and collagen bundles (Villegas and Villegas, 1984). Figure $4 b$ shows the labeling pattern of the giant axon with the aNFP antibody. The giant axon is intensely labeled; there is no labeling of the glial elements or connective tissue. While the aIFA antibody does label the giant axon, the degree of labeling is less than that with the aNFP antibody (Fig. $4 c$ ). In contrast to the aNFP antibody, the aIFA antibody labeled the glial cell surrounding the giant axon intensely (Fig. $4 c$ ). No labeling of the surrounding connective tissue was seen with the aIFA antibody.

Stellate ganglion. Figure 5 shows the results of 2 experiments $(a-c, d-f)$ in which serial sections of the stellate ganglion were stained with aIFA and aNFP monoclonal antibodies. The stellate ganglion consists of neurons or ganglion cells $(\sim 50 \mu \mathrm{m}$ in diameter) surrounded by glial cells. The ganglion cells are arranged in sets. In each set, the axons extending from the ganglion cells fuse to form a giant axon that innervates the mantle muscles; the hindmost and longest of these is known as the squid giant axon and forms the postsynaptic part of the giant synapse (Young, 1939; Villegas and Villegas, 1984). These axons will synapse with the thinnest of the terminal branches of a secondorder axon from the palliovisceral ganglion behind the magnocellular lobe. Figure $5 a$ is a toluidine blue-stained semithin section of a portion of the stellate ganglion where axons emerge. The neuropil of the ganglion consists of axons and synapses between the second-order fibers from the palliovisceral lobes 
and the third-order fibers, i.e., the giant axons of the stellate ganglion. Figure $5 b$ shows labeling of these regions by the aIFA antibody. Labeling is associated with nuclear membranes of ganglion and glial (micrograph not shown) cells and glial cells themselves. The axons and general cytoplasm within the cell bodies are labeled to a small extent. Figure $5 c$ shows the labeling pattern of a comparable area by the aNFP antibody; only the axons are intensely labeled. No label is detected in glial cells surrounding the axons and ganglion cells or within the ganglion cells themselves. Figure $5(d-f)$ shows another region of stellate ganglion. A group of ganglion cells surrounding some axons are seen in the toluidine blue section in Figure $5 d$. A comparable section, labeled by the aIFA antibody, is shown in Figure $5 e$. Glial cells in between ganglion cells are labeled as are nuclear membranes of ganglion cells. Only a low degree of labeling is seen in axons and ganglion cells. A different pattern is obtained by labeling a similar area with the aNFP antibody; in this case, only axons are labeled (Fig. $5 f$ ). A high-magnification view of ganglion cells stained with toluidine blue and a corresponding section labeled with the aIFA antibody are seen in Figure 6, $a$ and $b$, respectively. Glial cells surrounding ganglion cells are intensely labeled. Nuclear membranes of ganglion cells are also labeled. The general cytoplasm of ganglion cells is labeled to a small extent. Table 1 shows the relative amounts of immunoreactivity of aNFP and aIFA monoclonal antibodies in the giant axon and stellate ganglion as seen by light microscopic immunocytochemistry. No immunoreactivity was seen in control sections incubated with $1 \%$ NGS in TBS-BSA buffer or processed for silver enhancement without incubation with the primary antibody.

\section{Electron microscopic immunocytochemistry}

Giant axon. In thin sections of squid giant axon embedded in LR White, neurofilaments are seen to consist of a straight portion, $10 \mathrm{~nm}$ wide, interrupted at regular intervals, $\sim 20-40 \mathrm{~nm}$ long, by "beadlike" portions, $\sim 30 \mathrm{~nm}$ wide (Fig. 7). The micrograph seen in Figure $7 a$ was taken from a region where the neurofilaments are not closely packed and organized in bundles. In this section of the giant axon, which was exposed to the aNFP monoclonal antibody, colloidal gold particles label the neurofilaments (Fig. 7a). Specifically, the gold particles are associated with the beadlike portions located along the length of the neurofilament. In contrast to the extensive labeling of neurofilaments by the aNFP antibody, there was a markedly lower degree of labeling of neurofilaments by the aIFA antibody (Fig. $7 b$ ). Because of the sparsity of the labeling, the exact location of the subunit along the length of the filament could not be discerned. Figure 7, $c$ and $d$, shows details of labeling of neurofilaments by the aNFP antibody. The micrographs were taken from a region of the axoplasm where the neurofilaments were more closely packed than these in the previous micrographs. Colloidal gold particles are seen to be specifically associated with the beadlike portions of the neurofilament. Fine filamentous material was often seen to project at right angles to the neurofilament, specifically from the beadlike portions. These thinner filaments, $\sim 5 \mathrm{~nm}$ in diameter, are comparable to the crossbridge associations previously described in the squid (Hodge and Adelman, 1980, 1983; Rice et al., 1980; Metuzals et al., $1982,1983 \mathrm{a}, \mathrm{b})$, as well as in other organisms (Ellisman and Porter, 1980; Ellisman, 1981; Willard and Simon, 1981; Sharp et al., 1982; Hirokawa et al., 1984) and form ladderlike patterns
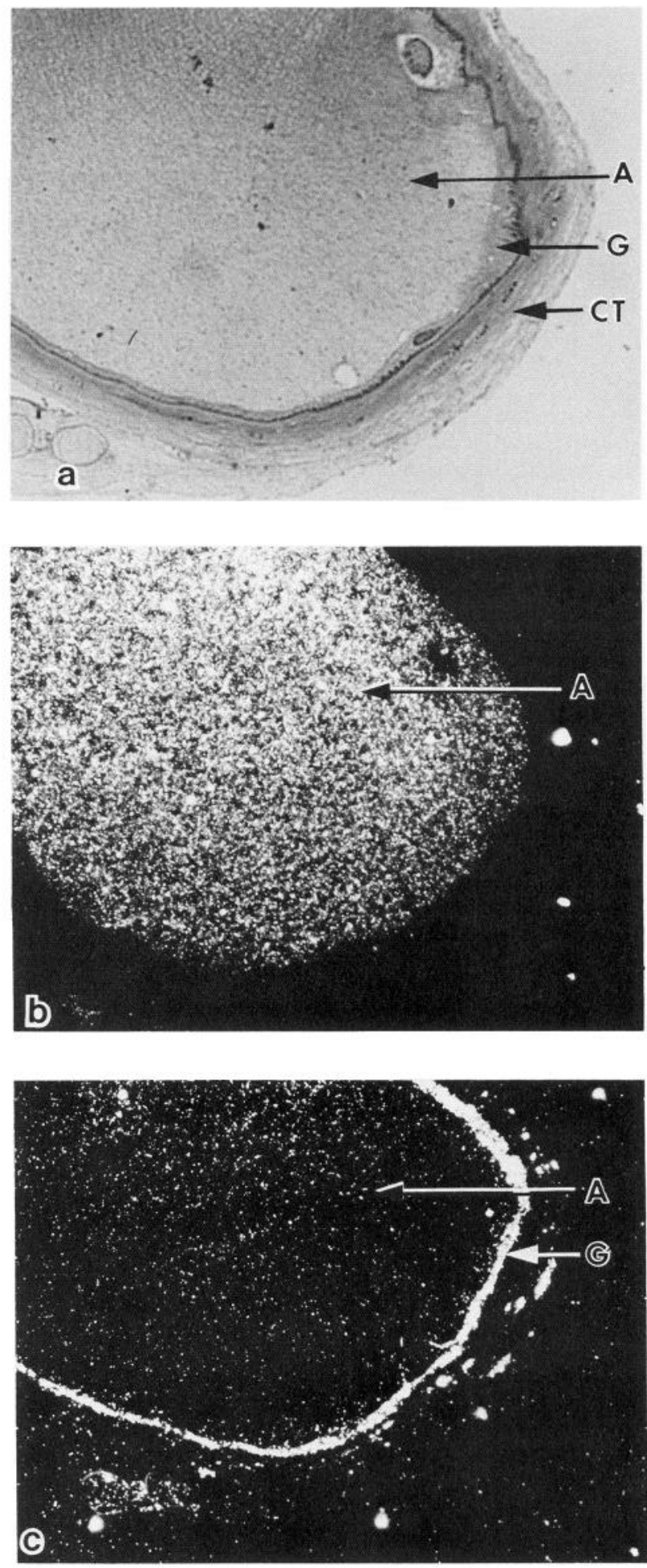

Figure 4. Light micrograph of tangential semithin sections of the giant axon stained with toluidine blue $(a)$ or labeled with aNFP $(b)$ or aIFA (c) monoclonal antibodies and processed using the silver enhancement procedure. $a$, The giant axon preparation consists of 3 components: the axon $(A)$, the glial cell $(G)$ surrounding the axon, and the outer connective tissue layer $(C T)$ surrounding the glial cells. $b$, Intense labeling of the giant axon $(A)$ by the aNFP antibody is seen. No labeling is seen in the glial cell or connective tissue elements. $c$, Labeling of the giant axon $(A)$ by the aIFA antibody is less intense than that seen with the aNFP antibody. In contrast, intense labeling of the glial cell $(G)$ is seen around the giant axon $(A) \times 416$. 

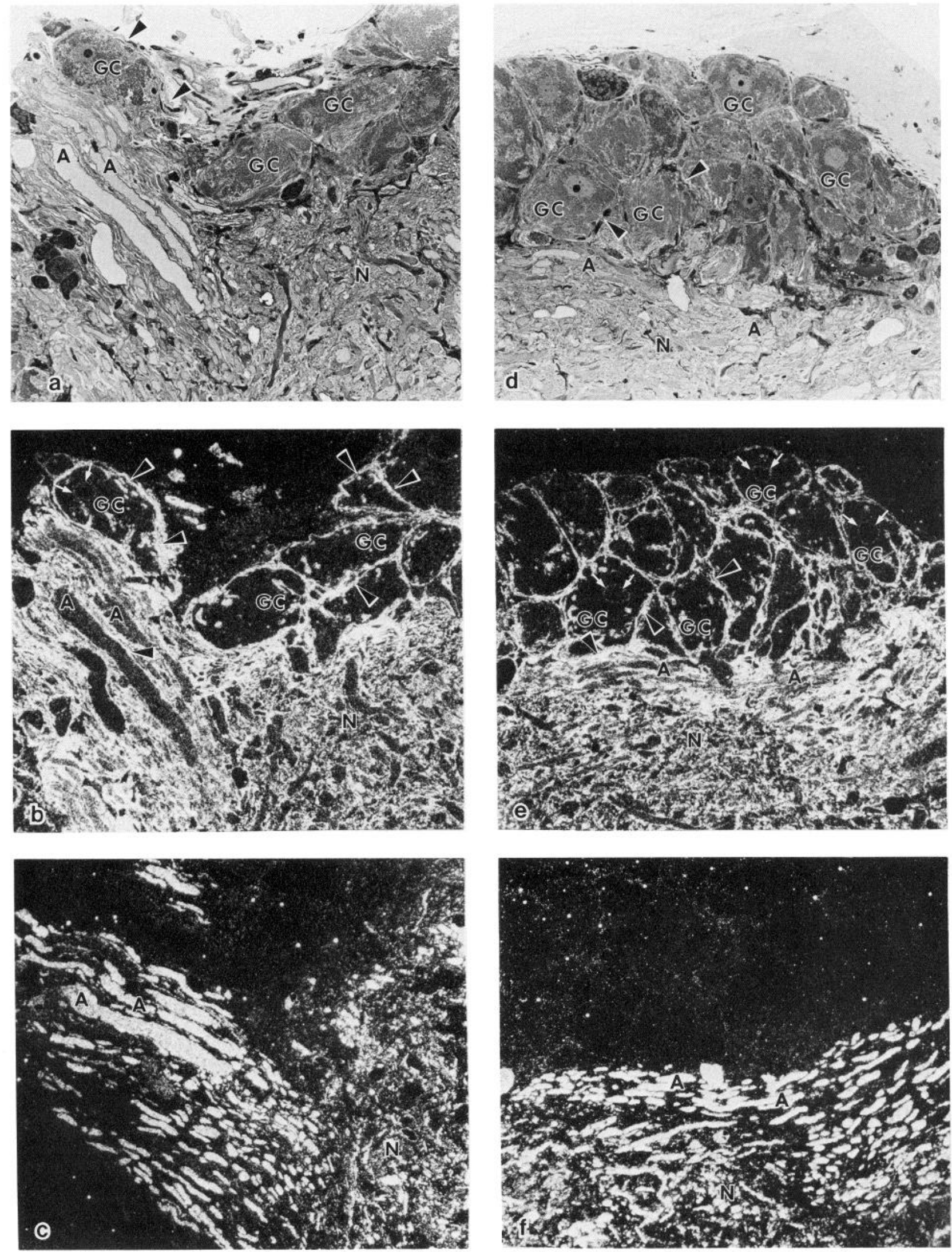

Figure 5. Light micrographs of semithin serial sections of the stellate ganglion where axons emerge stained with toluidine blue $(a, d)$ or labeled with aIFA $(b, e)$ or aNFP $(c, f)$ monoclonal antibodies and processed using the silver enhancement procedure. $a$ and $d$, Ganglion cells $(G C)$ surround the neuropil $(N)$ and an area containing several axons $(A)$. Arrowheads indicate glial elements. $b$ and $e$, Intense labeling by the aIFA antibody is seen predominantly in glial elements (arrowheads) surrounding ganglion cells $(G C)$ and axons $(A)$. Labeling is also detected in nuclear membranes (arrows) of ganglion cells. Moderate amounts of labeling are seen in the cytoplasm of ganglion cells and axons. $c$ and $f$, Labeling by the aNFP antibody is restricted to axons $(A)$ within the stellate ganglion. No reactivity is seen within ganglion or glial cells. $\times 178$. 

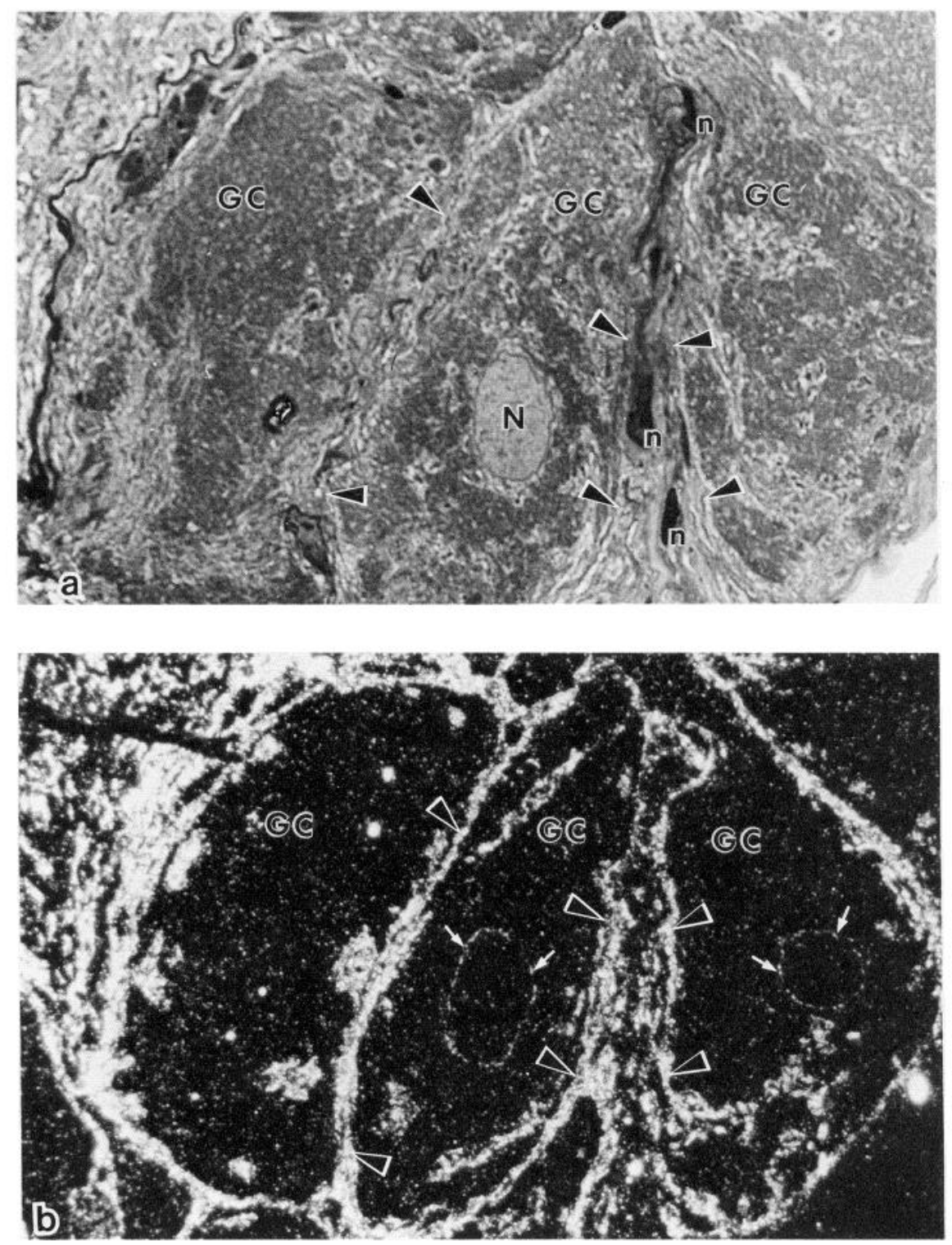

Figure 6. High magnification light micrograph of a semithin section showing stellate ganglion cells stained with toluidine blue $(a)$ or labeled with the aIFA antibody $(b)$ and processed using the silver enhancement procedure. $a$, Stellate ganglion cells $(G C)$ are surrounded by glial elements (arrowheads). $N$, nucleus of ganglion cell; $n$, nucleus of glial cell. $b$, Corresponding section incubated with the aIFA antibody shows intense labeling of glial elements (arrowheads) surrounding ganglion cells $(G C)$. Nuclear membranes are labeled (arrows). Some labeling is also seen in the cytoplasm. $\times 514$.

between parallel neurofilaments. Apparent cross-bridges also show beadlike portions, although they are somewhat smaller $(\sim 8-16 \mathrm{~nm})$ than those on the main portion of the neurofilament (Fig. 7, $c$ and $d$ ). Both the putative cross-bridge itself and its beadlike portions are labeled by the aNFP monoclonal antibody (Fig. 7, $c$ and $d$ ).

Differences in the labeling pattern between the aNFP and aIFA monoclonal antibodies were also seen in the glia surrounding the giant axon. Figure $8 a$ shows filaments in a section of a glial cell surrounding the giant axon. In contrast to the neurofilaments located within the axon, the $10 \mathrm{~nm}$ glial filaments are relatively smooth (Fig. 8). Figure $8 a$ shows that sections incubated with the aIFA antibody contain colloidal gold particles that label the glial filaments. Another view of labeling of glial filaments by the aIFA antibody is shown in Figure $8 b$. In this figure, the relatively smooth surface of the glial filaments can be seen and compared to the nodose contours of the neurofilaments seen in the accompanying micrographs of Figure 7 . When similar glial sections were incubated with aNFP antibody, no colloidal gold labeling was observed (not illustrated).

Stellate ganglion. In the stellate ganglion, there was a small amount of labeling of the neurofilaments within axonal processes by the aIFA antibody (Fig. $9 a$ ). As in the giant axon, the immunoreactivity within these smaller axons was markedly greater for the aNFP antibody (Fig. $9 b$ ) than for the aIFA antibody. Labeling by the aNFP antibody in the stellate ganglion was confined to neurofilaments within axonal processes. In contrast, the aIFA antibody labeled several areas within the stellate ganglion. In addition to axons, specific sites were labeled within ganglion and glial cells, although in varying degrees.

Ganglion cells usually possessed a varying number of "islands" of filaments within the cytoplasm (see Fig. 10). These islands were round, elongated, or irregularly shaped and were surrounded by rough endoplasmic reticulum. Moderate amounts of labeling of these filaments by the aIFA antibody are seen in Figure $10 \mathrm{a}$. Only negligible amounts of labeling of these fila- 


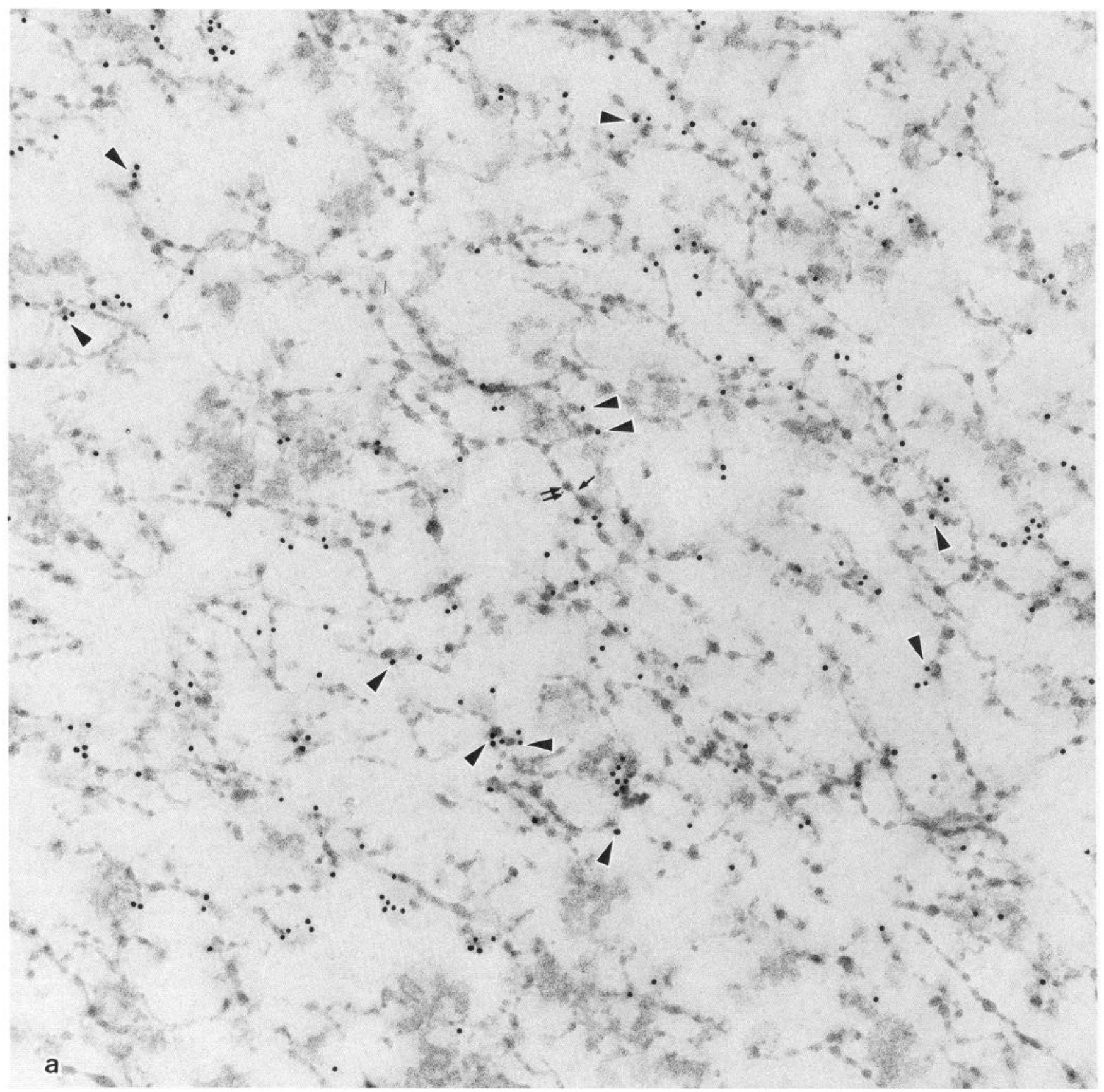

Figure 7. High-magnification electron micrographs of sections of squid giant axon incubated with the aNFP monoclonal antibody $(a, c, d)$ or aIFA monoclonal antibody $(b)$ and secondary antibodies labeled with $10 \mathrm{~nm}$ colloidal gold. Neurofilaments are seen to consist of a straight portion

ments by aNFP were seen (Fig. 10b). The filaments comprising these islands were relatively smooth compared to the neurofilaments, although occasionally fine strands of material could be seen to extend from them (Fig. 10b). A few round, dense structures, between $\sim 80$ and $160 \mathrm{~nm}$ in diameter, were seen within the island and in close association with the network of filaments comprising the island (Fig. 10b).

One of the most striking areas of labeling by the aIFA antibody was in filaments of glial cells (Fig. 11) in between the ganglion cells. Bundles of relatively smooth filaments (Fig. 11a) showed strong reactivity to this antibody but no reactivity to the aNFP antibody (Fig. $11 \mathrm{~b}$ ). Synapses in the neuropil of the stellate ganglion were examined for reactivity to both the aNFP and
aIFA monoclonal antibodies. These antibodies did not label the presynaptic terminal, the synaptic vesicles, the postsynaptic process, or the cleft region (not illustrated). Table 1 summarizes the relative amounts of labeling by both monoclonal antibodies in the giant axon and stellate ganglion seen in the EM. No immunoreactivity was detected in control sections incubated with $1 \%$ NGS in TBS-BSA buffer.

\section{Discussion}

In this study we used 2 monoclonal antibodies to evaluate the phosphorylation state of the $220 \mathrm{kDa}$ neurofilament protein in various topographical regions in squid neurons. The squid giant axon and the neuronal perikarya in the stellate ganglion are 

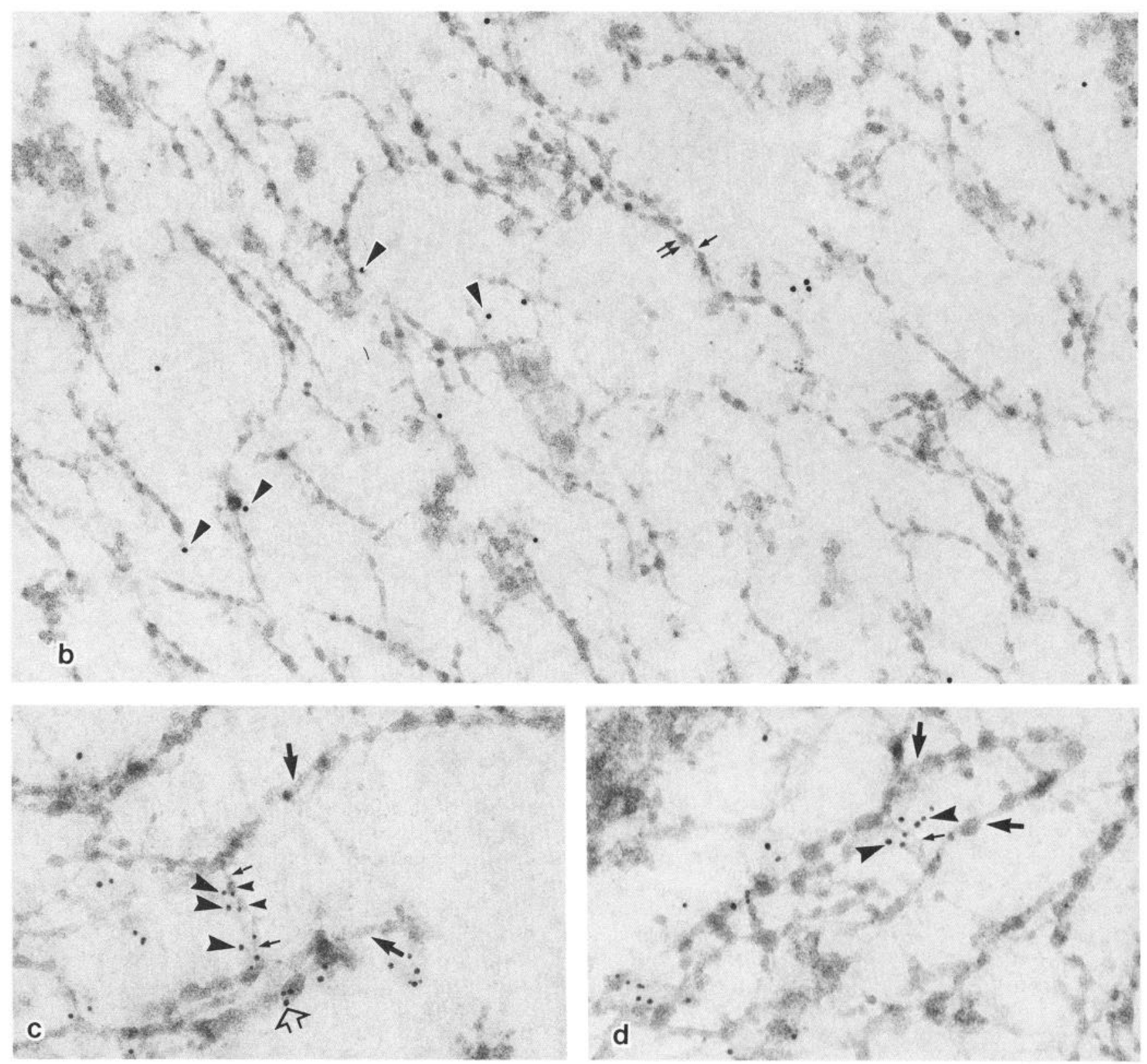

(arrow) interrupted at regular intervals by "beadlike" portions (double arrows). Extensive labeling of the neurofilaments by the aNFP antibody (a) is seen, whereas the labeling by aIFA $(b)$ is markedly lower. Arrowheads indicate colloidal gold particles associated with the beadlike portions on the neurofilaments. $\times 75,000$. Higher magnifications $(\times 120,000)$ of the aNFP-labeled neurofilaments are shown in $c$ and $d$. Note that colloidal gold particles (large arrowheads) are associated with the small beadlike portions (small arrowheads) and on putative cross-bridges between 2 neurofilaments (large arrows). The open arrow indicates colloidal gold labeling of the beadlike portion on an adjacent neurofilament. $\times 120,000$.

excellent systems for such a study since both can be evaluated experimentally by biochemical as well as immunocytochemical procedures. Two posttranslational mechanisms are known to modify HMW neurofilaments: phosphorylation by specific protein kinases and proteolysis by calcium-activated neutral proteases (CANPs). The phosphorylation of neurofilaments is most extensive in the HMW neurofilament protein subunits, i.e., there are about $9-11$ and $22 \mathrm{~mol}$ phosphate/mol of 150 and $200 \mathrm{kDa}$ mammalian neurofilament polypeptides, respectively (Julien and Mushynski, 1982; Georges et al., 1986). Similarly, the $220 \mathrm{kDa}$ neurofilament protein in the squid axon contains $>20 \mathrm{~mol}$ phosphate/mol polypeptide (P. A. M. Eagles, personal communication). These phosphates appear to be largely located in the carboxyl-terminal tail domains of the neurofilament proteins (Julien and Mushynski, 1983; Gallant et al., 1986; Pant et al., 1986), and their functional significance is largely speculative at present. The neurofilament proteins are also acted upon by specific proteases (CANPs) present in axoplasm (Gilbert et al., 1975; Pant and Gainer, 1980; Pant et al., 1982) but normally do not become activated until the neurofilaments enter the nerve terminals (Lasek and Hoffman, 1976; Pant et al., 1982; Schlaepfer and Zimmerman, 1985).

In this paper we have used the 2 monoclonal antibodies aIFA and aNFP to determine whether the phosphorylation of the 220 $\mathrm{kDa}$ squid neurofilament is similarly topographically regulated in the neuron. That such regulation occurs is suggested by im- 
Table 1. Relative immunoreactivity of aNFP and aIFA monoclonal antibodies in squid giant axon and stellate ganglion as determined by light and electron microscopic immunocytochemistry

\begin{tabular}{|c|c|c|c|c|}
\hline \multirow[b]{2}{*}{ Tissue source or protein } & \multicolumn{2}{|c|}{ Light microscopy } & \multicolumn{2}{|c|}{ Electron microscop } \\
\hline & aNFP & aIFA & aNFP & aIFA \\
\hline \multicolumn{5}{|l|}{ Giant axon } \\
\hline Axon & +++ & + & $++t$ & + \\
\hline Glia around axon & - & +++ & - & ++ \\
\hline \multicolumn{5}{|l|}{ Stellate ganglion } \\
\hline Ganglion cell body (cytoplasm) & - & + & - & + \\
\hline "Islands" of filament within ganglion cell & \multicolumn{2}{|c|}{ Not visible } & - & ++ \\
\hline Nuclear membranes of ganglion cells & - & ++ & - & ++ \\
\hline Axons & +++ & + & +++ & + \\
\hline Synapses & \multicolumn{2}{|c|}{ Not visible } & - & - \\
\hline Glial cells/filaments & - & +++ & - & $+t+$ \\
\hline Nuclear membranes of glial cells & - & ++ & - & ++ \\
\hline
\end{tabular}

The relative immunoreactivity of aNFP and aIFA monoclonal antibodies in squid giant axon and stellate ganglion was determined by Western blots and by light and electron microscopy. On Western blots, the aNFP antibodies labeled the $220 \mathrm{kDa}$ and HMW proteins in axoplasm; no labeling by this antibody was seen in the stellate ganglion. In contrast, the alFA antibody labeled the $60 \mathrm{kDa}$ protein in axoplasm and the $60 \mathrm{kDa}$ and $65 \mathrm{kDa}$ proteins in the stellate ganglion. The aIFA antibody also labeled the dephosphorylated form of the $220 \mathrm{kDa}$ protein, i.e., the $190 \mathrm{kDa}$ protein. Immunocytochemical studies showed that labeling by the aNFP antibody was restricted to the giant axon and smaller axons within the stellate ganglion. Labeling by the aIrA antibody was seen in the giant axon to some cxtent but to a greater degree in the glial cells surrounding the giant axon. In addition, the aIFA antibody labeled several areas within stellate ganglion cells, including "islands" of filaments and nuclear membranes. Intense labeling by the aIFA antibody of glial cells surrounding axons and ganglion cells was seen. Symbols: +++ , intensely stained; ++ , moderately stained; + , weakly stained; - , negative.

munocytochemical analyses of phosphorylated neurofilament epitopes in mammalian systems (Sternberger and Sternberger, 1983), and the observation of a putative neurofilament protein kinase inhibitor in squid neuronal perikarya preparations (Pant et al., 1986).

\section{Specificities and properties of the aIFA and aNFP monoclonal antibodies}

The aIFA antibody rcacts with all intermcdiatc filaments, including neurofilaments (Pruss et al., 1981; Pruss, 1985). The epitope recognized by aIFA is located in the highly conserved rod domain of all intermediate filament proteins (Geisler et al., 1983; Phillips et al., 1983; Cooper et al., 1984); hence, reaction with this antibody can be used as an identification criterion for intermediate filament proteins in Western blot procedures. As can be seen in Figure 1, aIFA staining of Western blots of squid axoplasm detect several positive bands, including the 60 and $190-220 \mathrm{kDa}$ neurofilament proteins. These have previously been identified as neurofilament proteins by biochemical (Pant et al., 1978; Zackroff and Goldman, 1980; Tytell et al., 1985) and Bodian silver staining (Phillips et al., 1983) methods. The HMW neurofilament protein in squid axoplasm does not appear to react with aIFA (Fig. 1) and reacts poorly with the Bodian silver stain (Phillips et al., 1983). However, we identify the HMW protein in squid axoplasm as a neurofilament protein for several reasons: (1) It can react with aIFA under special conditions of staining (Pruss et al., 1981; Pruss, 1985); (2) it copurifies with 60 and $220 \mathrm{kDa}$ proteins in neurofilament preparations from squid axoplasm (Pant et al., 1978, 1986); (3) it is phosphorylated by the squid neurofilament protein kinase (Pant et al., 1986) and is degraded by the CANP in squid axoplasm (Gallant et al., 1986); and (4) the HMW protein reacts strongly with the aNFP antibody, which otherwise reacts only with the $220 \mathrm{kDa}$ neurofilament protein (Fig. 1). Given these data, we believe that the HMW protein (ca. $400 \mathrm{kDa}$ ) is a covalently linked dimer of the $220 \mathrm{kDa}$ protein in squid axoplasm. The aIFA antibody reacts poorly with the phosphorylated form of the $200 \mathrm{kDa}$ neurofilament protein. However, when this protein is extensively dephosphorylated by alkaline phosphatase, its reactivity is greatly increased (Fig. $3 C$ ). This suggests that the phosphates removed by this procedure were either sterically hindering access to or allosterically altering the state of the unphosphorylated epitope recognized by this antibody. This, in part, could account for the relatively weak labeling of axoplasm and neurofilaments by this antibody in immunocytochemical procedures (Figs. $4 c, 7 b$ ). Another reason for its weak labeling in immunocytochemical procedures is that the epitope of aIFA is located in the conserved rod domain of the molecule, which is involved in the coiled-coil structure of the neurofilaments. It is likely that after fixation of the tissue, these epitopes would be fixed in a location relatively inaccessible to the antibody. This is consistent with the general finding that antibodies to core domains (as opposed to end domains) of intermediate filaments perform relatively poorly in immunocytochemistry (Trojanowski et al., 1985).

In contrast to the aIFA antibody, the aNFP antibody used here to identify the phosphorylated end domain of the $220 \mathrm{kDa}$ neurofilament protein is very effective in both Western blot (Figs. 1, 3) and immunocytochemical (Figs. $4 b ; 5, c, f ; 7 a$ ) procedures. Hence, the lack of reactivity with Western blots of stellate ganglion cell body protein preparations (Fig. 1) and in immunocytochemistry of cell bodies (Fig. 5, b, c), as opposed to its strong reactivity in immunocytochemistry of axons (Figs. $4 b ; 5, c, f)$, argues strongly that the phosphorylated epitope in the $220 \mathrm{kDa}$ protein recognized by aNFP is restricted to axonal regions in the neuron. It should be clarified here that these data do not directly address the issue whether all phosphorylation of the neurofilaments occurs solely intra-axonally. Since there are more than 20 phosphate groups in the end domain of the $220 \mathrm{kDa}$ neurofilament protein, it is unlikely that aNFP (or any 

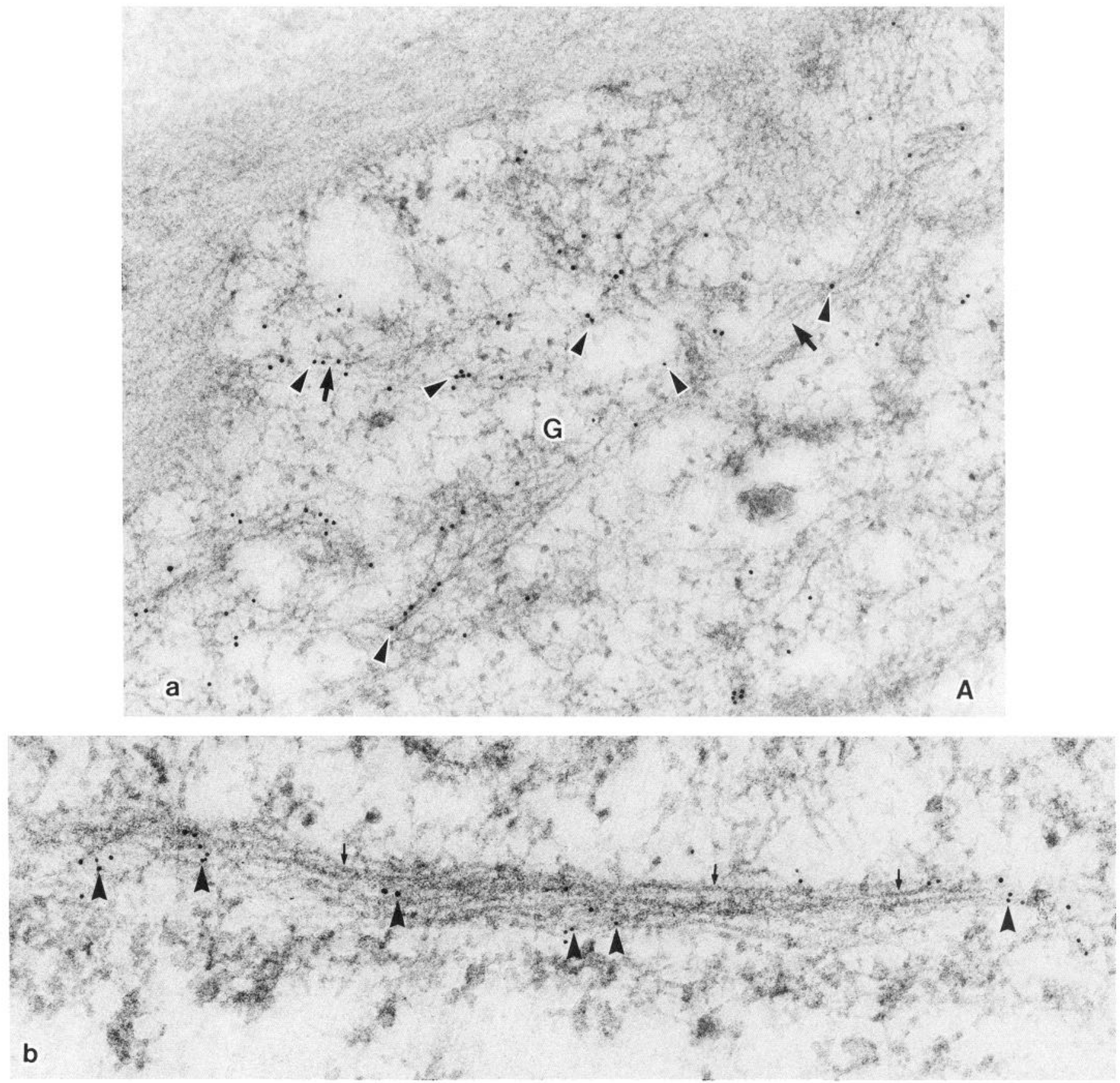

Figure 8. High-magnification electron micrographs of sections of glial cells $(G)$ surrounding a giant axon $(A)$ incubated with aIFA monoclonal antibodies and secondary antibodies labeled with $10 \mathrm{~nm}$ colloidal gold. $a$ and $b$, Colloidal gold particles (arrowheads) are associated with relatively smooth filaments (arrows), usually arranged in bundles, within the glial cell. $\times 75,000$. Similar experiments using aNFP antibodies showed virtually no glial labeling (not illustrated).

single antibody) could detect all of these. The data in Figure $3 B$ show that aNFP detects a phosphorylated epitope and that this epitope can be removed by incubation with $60 \mu \mathrm{g}$ alkaline phosphatase. However, the data in Figure $3, A$ and $C$, also show that at this concentration $(60 \mu \mathrm{g})$ of enzyme the $220 \mathrm{kDa}$ protein has not yet reached its "fully dephosphorylated" state of $190 \mathrm{kDa}$. The latter form appeared to require $200 \mu \mathrm{g}$ of enzyme. Presumably between 60 and $200 \mu \mathrm{g}$ of enzyme incubation other phosphates not detected by aNFP were being removed from the 220 kDa neurofilament protein. Recently, Georges et al. (1986) have shown that exhaustive alkaline phosphatase treatment of the $200 \mathrm{kDa}$ mammalian neurofilament protein, which lowered the apparent molecular weight of this protein on SDS gels, did not fully dephosphorylate the protein. After the phosphatase treatment the protein still contained $8 \mathrm{~mol}$ phosphate/mol polypeptide, as compared to the original value of $22 \mathrm{~mol}$ phosphate/ mol polypeptide (Georges et al., 1986). Hence, it is likely that the $190 \mathrm{kDa}$ "dephosphorylated" neurofilament protein seen in Figures 2 and 3 also contains some residual phosphates. Therefore, by using aNFP as an immunological probe in these studies, 

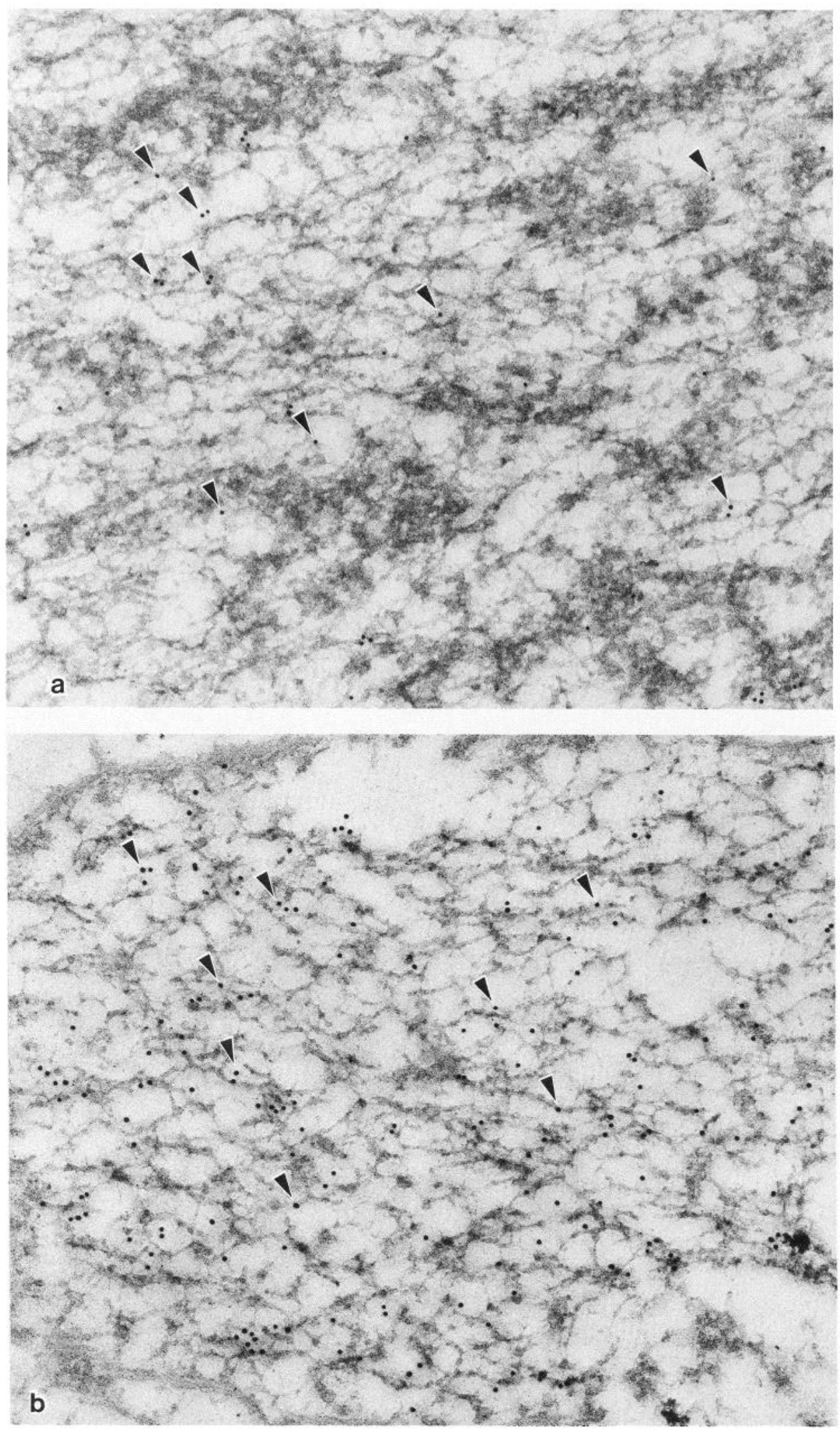

Figure 9. High-magnification electron micrograph of sections of small axons located within the stellate ganglion incubated with aIFA (a) and aNFP $(b)$ monoclonal antibodies and secondary antibodies labeled with $10 \mathrm{~nm}$ colloidal gold. $a$, A moderate number of colloidal gold particles (arrowheads) are associated with filaments in small axons within a section of the stellate ganglion incubated with aIFA antibody. $b$, A large number of colloidal gold particles (arrowheads) are associated with filaments in small axons within the stellate ganglion incubated with aNFP antibody. $\times 60,000$. 

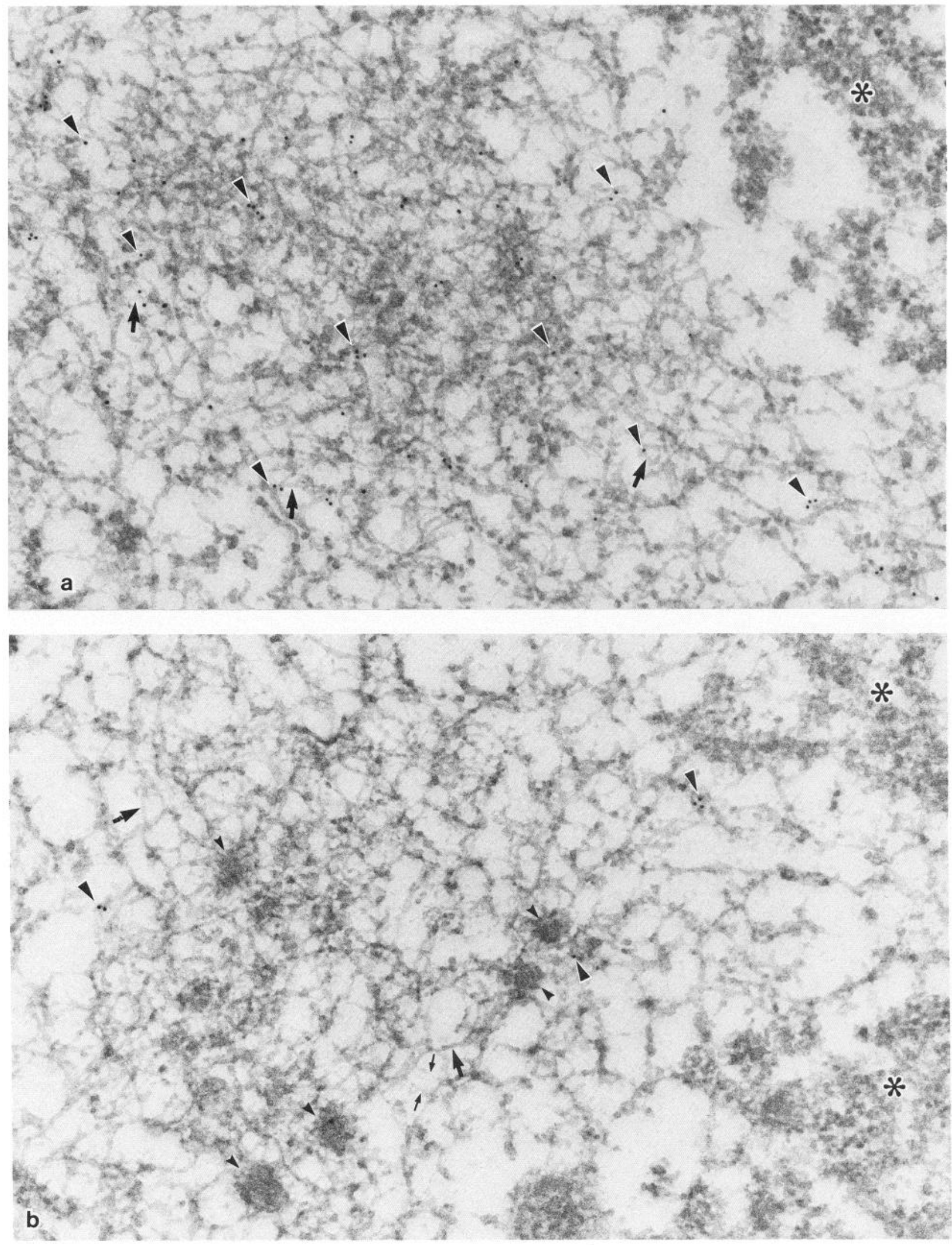

Figure 10. High-magnification electron micrograph of sections of "islands" of filaments in stellate ganglion cells incubated with aIFA $(a)$ or aNFP (b) monoclonal antibodies and secondary antibodies labeled with $10 \mathrm{~nm}$ colloidal gold. a, Colloidal gold particles (arrowheads) indicate labeling by aIFA antibody of an extensive network of filaments (arrows) located in between areas of rough endoplasmic reticulum (asterisk). $b$, Negligible amounts of colloidal gold labeling (arrowheads) by aNFP antibody are seen in an extensive network of filaments (large arrows) located in between areas of rough endoplasmic reticulum (asterisks). Dense bodies (small arrowheads) are interspersed within the island of filaments and are in close association with the filamentous network. Occasionally, fine strands of material (small arrows) are seen between adjacent filaments. $\times 60,000$. 

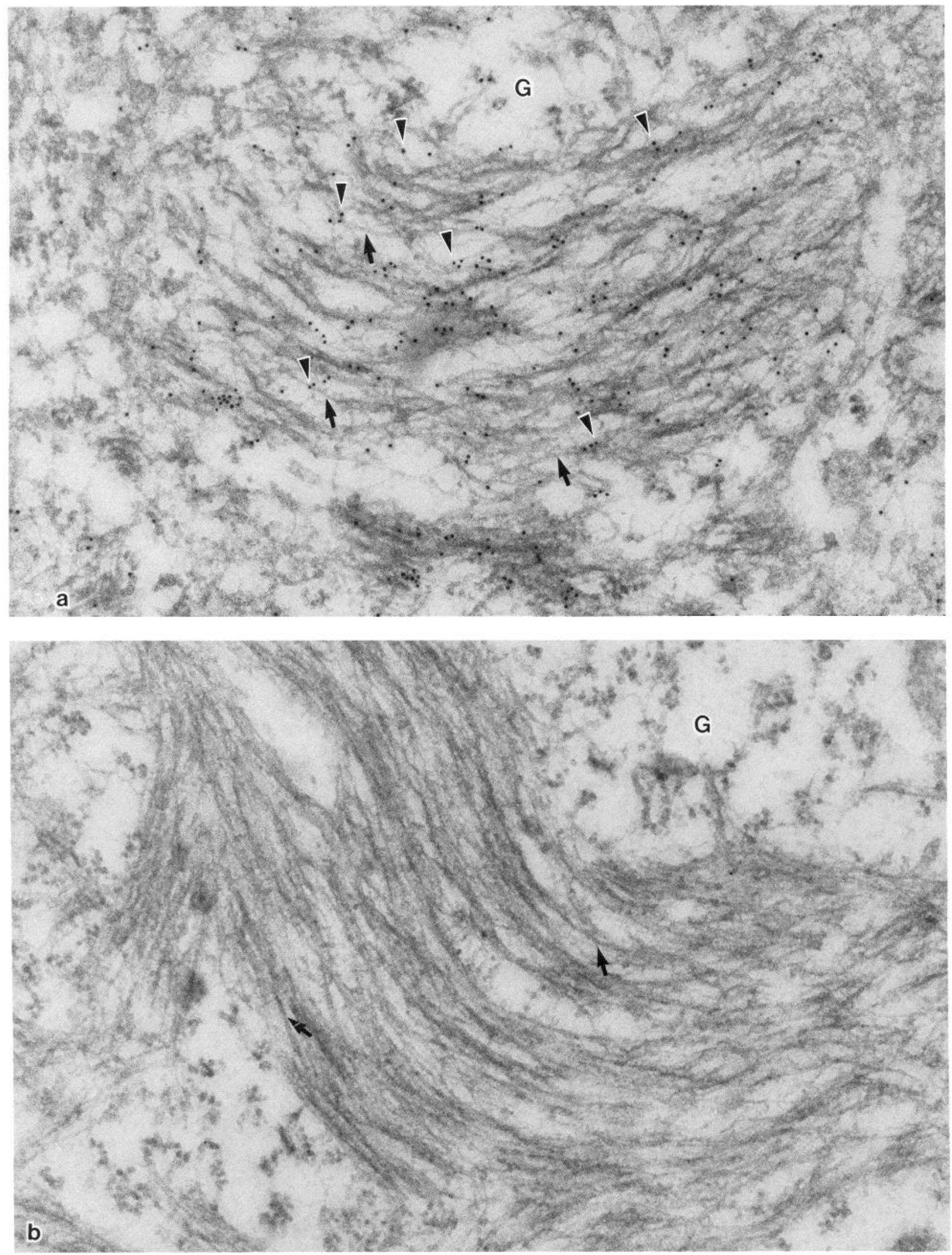

Figure 11. High-magnification electron micrographs of relatively smooth filaments in sections of glial cells $(G)$ in the stellate ganglion incubated with aIFA $(a)$ or aNFP $(b)$ monoclonal antibodies and to secondary antibodies labeled with $10 \mathrm{~nm}$ colloidal gold. $a$, Colloidal gold particles (arrowheads) indicate extensive labeling of relatively smooth glial filaments (arrows) by the aIFA antibody. $b$, Relatively smooth glial filaments (arrows) show no immunoreactivity for the aNFP antibody. $\times 60,000$. 


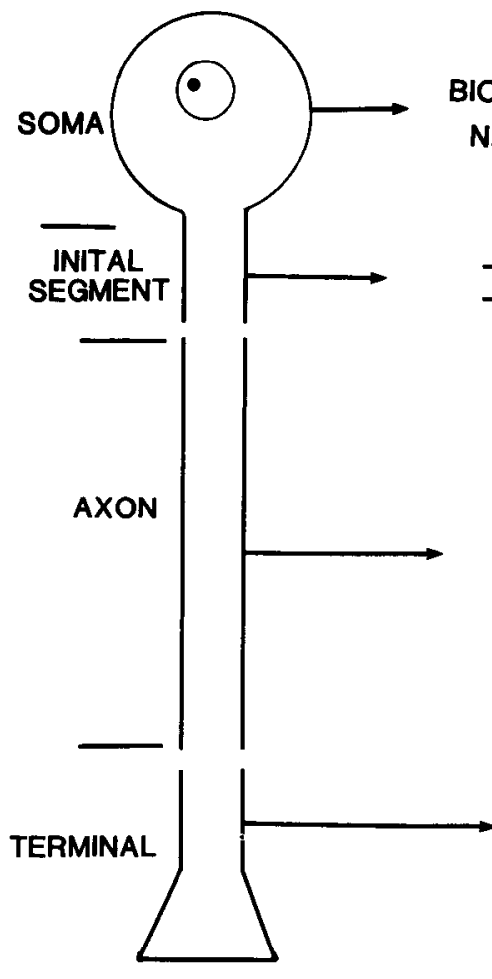

BIOSYNTHESIS OF 60kd AND 190kd NFP SUBUNITS AND ASSEMBLY. $\nabla$
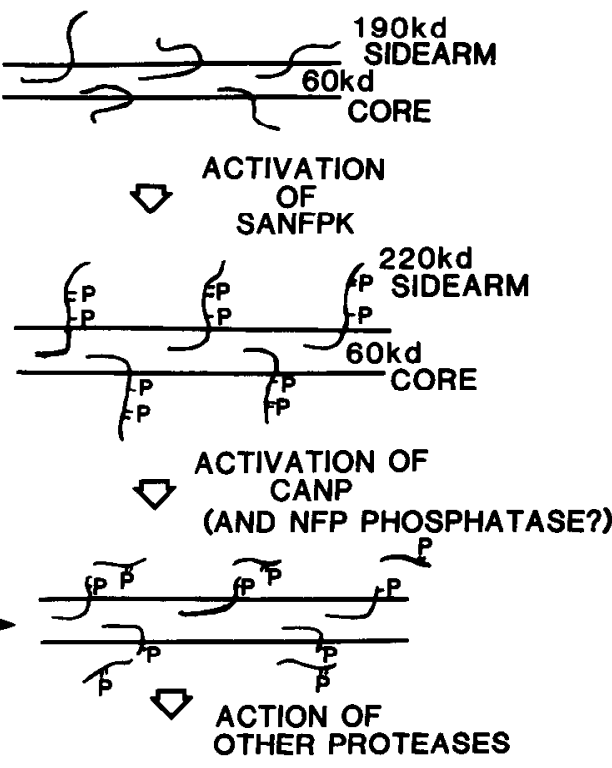

DEGRADATION OF NFP

Figure 12. Model for the topographical regulation of neurofilaments in squid stellate ganglion neurons. The 60 and $190 \mathrm{kDa}$ neurofilament protein subunits-representing the putative core and unphosphorylated side-arm neurofilament components, respectively, in the squid-are synthesized and assembled for axonal transport in the cell body. This is consistent with the ability of the aIFA antibody to stain islands of smooth intermediate filaments in the cell body and the absence of aNFP (phosphorylated epitope) staining in the cell body. Since the appearance of aNFP staining is exclusively located in axonal structures both in the stellate ganglion and in the giant axon, we interpret this to mean that activation of the squid axon ncurofilament protein kinase $(S A N F P K)$ is initiated somewhere in the region of the axonal initial segment (axon hillock), possibly regulated by an inhibitor of the SANFPK located in the cell body (see Pant et al., 1986). In the giant axon, there is very little $190 \mathrm{kDa}$ subunit, and virtually all of the HMW neurofilament protein subunits are either in the 220 or $>400 \mathrm{kDa}$ form (i.e., the HMW component), both of which stain intensely with aNFP (Fig. 1) and are heavily phosphorylated by SANFPK. Both the $220 \mathrm{kDa}$ and HMW proteins (we believe the HMW is a covalently linked $220 \mathrm{kDa}$ dimer, unique to the giant axon) are greatly modified and rendered unreactive to aNFP by alkaline phosphatase treatment (Figs. 2 and 3). The absence of detectable $60 \mathrm{kDa}, 220 \mathrm{kDa}$, or HMW proteins in the nerve terminal by either immunocytochemical (not illustrated) or biochemical (Pant et al., 1982) methods is consistent with the proposal that the degradation of neurofilaments occurs in this site, in part, by the activation of calcium-activated neutral protease (CANP) and possibly a neurofilament protein (NFP)-specific phosphatase (see Lasek and Hoffman, 1976; Pant et al., 1982).

we are evaluating the presence or absence of a particular phosphorylation epitope (or class of epitopes) in the HMW squid neurofilament protein. By using both of these characterized antibodies, we were able to correlate the staining patterns and intensities on Western blots with the immunocytochemical data so as to obtain a view of these specific epitopes in the context of neuronal morphology in the squid.

\section{Immunocytochemical evidence for the topographic regulation of neuroflament protein phosphorylation}

Only small axons within the stellate ganglion show immunocytochemical labeling by the aNFP antibody (Figs. 5, $c, f ; 9 b$ ). In contrast, the aIFA antibody labels some of the stellate ganglion, particularly within the "islands" of filaments (Fig. 10a). These islands are areas rich in filaments, most of which have smooth contours, although some have projections emanating from their surface. An interesting feature is the presence of dense bodies interspersed and in continuity with the filaments com- prising the islands (Fig. 10b). Similar structures have been reported by Zackroff and Goldman (1980) in isolated intermediate filament (neurofilament) preparations during purification by 2 cycles of assembly and disassembly and by Metuzals et al. (1983b) in fractions enriched with neurofilament protein complex. Zackroff and Goldman (1980) proposed that the dense bodies may function in neurofilament nucleation or organization. In this regard, we have also seen several dense bodies arranged in a compact group (not illustrated). Some filaments could be discerned emanating from the group and among the dense bodics within it. It may be that the disposition of these dense bodies in the present micrographs reflects their functional state. That is, when filament synthesis and/or assembly is in a quiescent state, the dense bodies show a compact disposition. On the other hand, during or after active filament synthesis, the dense bodies become separated by greater distances due to the appearance of increased amount of filaments. Within the islands, most of the filaments are relatively smooth compared to axonal neurofila- 
ments, although occasionally thin filamentous strands, reminiscent of the cross-bridges seen in the axonal neurofilaments, project from the surface. Similar results were obtained by other investigators, who showed that while neurofilaments of cell bodies and dendrites were cross-linked, the cross-bridges in the cell bodies were fewer and shorter than those in the axons; in other studies, no reaction was observed with antibodies against the HMW component of neurofilaments and the cross-bridges between neurofilaments in the cell bodies (Hirokawa et al., 1984).

Because the dominant low-molecular-weight form of the neurofilament protein stained by aIFA on Western blots in axoplasm is $60 \mathrm{kDa}$ (Fig. 1), we presume that the aIFA-stained 60 $\mathrm{kDa}$ protein in the stellate ganglion blots in Figure 1 corresponds to the immunoreactive islands within the cell bodies (Fig. 10). However, the most intense staining by aIFA on the Western blots of the stellate ganglion is at $65 \mathrm{kDa}$. Since both the light and electron microscopic immunocytochemistry of the stellate ganglion indicates that the most intense labeling by the aIFA antibody occurred in the glial cells surrounding ganglion cells and axons, we conclude that the $65 \mathrm{kDa}$ protein very likely corresponds to glial intermediate filaments. Recent biosynthetic studics in which squid stellate ganglion cell bodies were incubated in vitro with ${ }^{3} \mathrm{H}$-leucine have shown a de novo synthesis of the $60 \mathrm{kDa}$ protein (Tytell et al., 1985). In addition, recent 2-dimensional gel analysis of squid cell bodies from the stellate ganglion combined with Western blot staining with aIFA and aNFP have revealed 60 and $190 \mathrm{kDa}$ aIFA immunoreactive proteins but no aNFP-immunoreactive $220 \mathrm{kDa}$ proteins (M. Tytell, H. C. Pant, W. D. Hill, and H. Gainer, unpublished observations).

These differences in the morphology and biochemical composition of neurofilaments in the axon and stellate ganglion suggest that phosphorylation of neurofilaments does not occur in cell bodies but in the axon. In contrast to the relatively smooth contours of neurofilaments seen in the stellate ganglion, neurofilaments from the squid giant axon embedded in LR White consist of a straight portion interrupted by beadlike portions and cross-bridges. This view of the neurofilament is consistent with that obtained from studies of the configuration and organization of the neurofilamentous network in the intact giant axon and isolated neurofilaments prepared and/or treated in various ways (Metuzals, 1969; Metuzals and Izzard, 1969; Hodge and Adelman, 1980, 1983; Rice et al., 1980; Metuzals et al., 1981 b, 1982, 1983a, b; Villegas and Villegas, 1984). LR White is a uscful cmbcdding medium for the visualization of the cytoskeleton and its associated structures because its low electron opacity permits the visualization of the fine filaments that would ordinarily be obscured in epoxy resins (Cohen et al., 1985). Using LR White, in the present case, various substructures comprising the neurofilament could be discerned. In addition, because the tissue was not exposed to osmium tetroxide before embedding in LR White, some structures appear negatively stained (Cohen et al., 1985). This property may account for the appearance of the beadlike portions of neurofilaments in the present study. Such a configuration has been seen in negatively stained, antibody-decorated (i.e., with antibodies to the HMW component) mammalian neurofilaments (Willard and Simon, 1981). We have observed filament morphologies and anti-IFA and anti-NFP labeling patterns in fixed neurofilamentenriched preparations prepared from axoplasm (not illustrated) that are very similar to those found in situ (Figs. 9, 10).

Western blots revealed that the aNFP antibody stained only the HMW and $220 \mathrm{kDa}$ proteins in the axoplasm. Parallel im- munocytochemical studies demonstrated that the aNFP antibody labeled primarily the beadlike portions and the fine filamentous cross-bridges, which is consistent with the observations of mammalian neurofilaments (Willard and Simon, 1981) described above and with the suggestion by others that an $\sim 380$ $\mathrm{kDa}$ protein (HMW in Fig. 1) in squid is attached to isolated 10 nm filaments and may be involved in cross-bridge structure (Rice et al., 1980; Metuzals et al., 1982, 1983b). Metuzals et al. (1982, 1983a, b) have tentatively assigned the $380 \mathrm{kDa}$ (HMW) and $220 \mathrm{kDa}$ polypeptides to the cross-linking, or radial, $5 \mathrm{~nm}$ filaments and the $60 \mathrm{kDa}$ polypeptide to the axial, or $10 \mathrm{~nm}$, filaments.

The aNFP antibody showed no immunoreactivity for the other major protein in axoplasm, i.e., the $60 \mathrm{kDa}$ protein, on Western blots. Intense immunoreactivity for this protein in the axoplasm and on Western blots was observed with the aIFA antibody. The corresponding ultrastructural results show only a small amount of immunoreactivity for this antibody in the giant axon. Greater amounts of labeling were seen by this antibody on filaments within the stellate ganglion cell bodies and glial cells around the giant axon and ganglion cells. These results suggest that while the the $60 \mathrm{kDa}$ protein is present in the neurofilaments of the axon, it is not readily accessible for immunocytochemical labeling under our fixation conditions. The filaments within the ganglion and glial cells show relatively smooth contours. The $60 \mathrm{kDa}$ polypeptide may therefore correspond to the straight portion of the neurofilament seen in between the beadlike portions. Immunocytochemical studies on mammalian neurofilaments have shown that its HMW polypeptide is a component of the cross-bridge between neurofilaments, whereas its low-molecular-weight polypeptide is primarily a component of the central core of the filaments (Willard and Simon, 1981; Sharp et al., 1982; Hirokawa et al., 1984). These studies are also in agreement with those on the in vitro assembly of neurofilaments from its high-, medium-, and low-molecular-weight components (Geisler and Weber, 1981; Moon et al., 1981; Liem and Hutchinson, 1982; Zackroff et al., 1982). The low-molecularweight component is necessary and sufficient for the formation of intermediate-filament-like structures, indicating its importance in the formation of the central core. When the HMW polypeptide is included in the reaction mixture, it is incorporated into the filaments. The resultant filaments show projections (Geisler and Weber, 1981; Moon et al., 1981) on the surface, demonstrating that a portion of the HMW component extends peripherally from their central cores.

With regard to their functional properties, both the $220 \mathrm{kDa}$ and HMW proteins are capable of being phosphorylated by endogenous kinases in whole axoplasm and neurofilament-enriched preparations as described above (Pant et al., 1978, 1979b, 1986). In the present study, dephosphorylation by alkaline phosphatase resulted in a decrease in molecular weights of the 220 kDa and HMW proteins, consistent with the removal of phosphorylated epitopes on both of these proteins. After dephosphorylation, immunochemical staining of the $220 \mathrm{kDa}$ and HMW proteins by the aNFP antibody on Western blots was eliminated, demonstrating that this antibody recognizes the phosphorylated epitope on the neurofilament molecule. The generation of a 190 $\mathrm{kDa}$ polypeptide that is not labeled by the aNFP antibody after phosphatase treatment of the $220 \mathrm{kDa}$ protein indicates that the latter consists of a phosphorylated epitope recognized by aNFP and a nonphosphorylated epitope recognized by aIFA. While dephosphorylation abolished immunochemical staining of the $220 \mathrm{kDa}$ and HMW proteins by the aNFP antibody, increasing 
concentrations of alkalinc phosphatase cnhanced immunochemical staining by aIFA of the apparent dephosphorylated form of the $220 \mathrm{kDa}$ protein, i.e., the $190 \mathrm{kDa}$ protein. In fact, the $190 \mathrm{kDa}$ protein became as intensely stained as the $60 \mathrm{kDa}$ protein. That the $190 \mathrm{kDa}$ polypeptide may be associated with the $60 \mathrm{kDa}$ protein of the neurofilament or share similar epitopes with this protein is suggested by its light staining with high titers of the aIFA antibody on Western blots of stellate ganglion preparations (Gallant et al., 1986). Similar results were obtained by Sternberger and Sternberger (1983) using tissue sections incubated with alkaline phosphatase. In these sections, they showed the appearance of reaction with antibodies staining only nonphosphorylated epitopes in structures that are usually stained only with antibodies to the phosphorylated epitopes, suggesting that dephosphorylation allows access to epitopes that were masked by phosphorylation (Sternberger and Sternberger, 1983). These results are comparable to those in the present study, as their dephosphorylated epitope reacted with an anti-perikaryonal-neurofibrillar antibody and the phosphorylated epitope reacted with an anti-neurofibrillar antibody. Comparable results were also reported by Glicksman and Willard (1985), who examined the dephosphorylation of the HMW component of mammalian neurofilaments and its subsequent loss of reactivity with antibodies to this polypeptide.

The final step in the regulation of neurofilament protein is its degradation by a $\mathrm{Ca}^{2+}$-activated protease which selectively degrades neurofilament proteins and copurifies with them (Pant et al., 1979a, 1982; Pant and Gainer, 1980; Gallant et al., 1986). This degradation appears to occur in the axon terminal, where an increase in $\mathrm{Ca}^{2+}$ fluxes may contribute to the activation of the protease (Lasek and Hoffman, 1976; Pant et al., 1982). Our present immunocytochemical study supports these findings, as no immunoreactivity for the aNFP or aIFA antibody was detected in presynaptic terminals (Table 1).

Our results on the regional distribution of neurofilament proteins are in agreement with those from other laboratories using mammalian neurofilaments. Several investigators have shown that neurofilament proteins are not phosphorylated in nerve cell bodies, their dendrites, and proximal axons but are highly phosphorylated in the axons themselves (Sternberger and Sternberger, 1983). Other studies have shown that the HMW protein is synthesized as a precursor which exhibits a change in isoelectric point and an increase in molecular weight with time (Oblinger and Schick, 1985). It was suggested that the long time course of processing of neurofilaments seen may be due to posttranslational modifications that occur as neurofilaments enter the initial axon segments by axonal transport (Oblinger and Schick, 1985). Furthermore, developmental studies indicate differences in the distribution of neurofilament components within the neuron (Willard and Simon, 1983). It has been proposed that, in the adult, phosphorylation may play a role in stabilizing compacted forms of neurofilaments among themselves or other cytoskeletal elements. This idea is in agreement with that of Metuzals et al. (1983b) suggesting that neurofilaments serve as a scaffold for other axonal components and that the cross-bridges determine the order within the neurofilamentous network.

The biochemical and immunocytochemical data presented here show differences in the distribution of nonphosphorylated and phosphorylated epitopes of neurofilaments in the soma, axon, and nerve terminal regions of squid neurons. These data and other studies on the squid nervous system (Pant et al., 1982, 1986; Gallant et al., 1986), as well as related work in the literature on mammalian neurofilaments (Lasek and Hoffman,
1976; Sternberger and Sternberger, 1983; Oblinger and Schick, 1985; Schlaepfer and Zimmerman, 1985) lend support to the hypothetical model illustrated in Figure 12, which summarizes the view that the formation, phosphorylation, and degradation of squid neurofilaments are topographically segregated in the neuron, i.e., biosynthesis and assembly in the cell body, phosphorylation in the axon, and degradation in the nerve terminal.

\section{References}

Ben-Barak, Y., J. T. Russell, M. H. Whitnall, K. Ozato, and H. Gainer (1985) Neurophysin in the hypothalamo-neurohypophysial system. I. Production and characterization of monoclonal antibodies. J. Neurosci. 5: 81-97.

Bendayan, M. (1983) Ultrastructural localization of actin in muscle, epithelial and secretory cells by applying the protein A-gold immunocytochemical technique. Histochem. J. 15: 39-58.

Cohen, R. S., S. K. Chung, and D. W. Pfaff (1985) Immunocytochemical localization of actin in dendritic spines of the cerebral cortex using colloidal gold as a probe. Cell. Mol. Neurobiol. 5: 271-284.

Cooper, D., A. Schermer, R. M. Pruss, and T. T. Sun (1984) The use of aIF, $\mathrm{AE} 1$, and $\mathrm{AE}_{3}$ monoclonal antibodies for the identification and classification of mammalian epithelial keratins. Differentiation 28: $30-55$.

Craig, S., and C. Miller (1984) LR White resin and improved on-grid immunogold detection of vicilin, a pea seed storage protein. Cell Biol. Int. Rep. 80: 879-886.

Danscher, G. (1981) Localization of gold in biological tissue. A photochemical method for light- and electron-microscopy. Histochemistry 71: $81-88$.

Danscher, G., and J. O. R. Norgaard (1983) Light microscopic visualization of colloidal gold on resin-embedded tissue. J. Histochem. Cytochem. 31: 1394-1398.

De Mey, J. (1984) Colloidal gold as marker and tracer in light and electron microscopy. Electr. Microsc. Soc. Am. Bull. 14: 54-66.

Eagles, P. A. M., D. S. Gilbert, and A. Maggs (1981) The location of phosphorylation sites and $\mathrm{Ca}^{2+}$-dependent cleavage sites on the major neurofilament polypeptides from Myxicola infundibulum. Biochem. J. 199: 101-111.

Ellisman, M. H. (1981) Beyond neurofilaments and microtubules. Neurosci. Res. Prog. Bull. 19: 43-58.

Ellisman, M. H., and K. R. Porter (1980) Microtrabecular structure of the axoplasmic matrix: Visualization of cross-linking structures and their distribution. J. Cell Biol. 87: 464-479.

Gallant, P. E., H. C. Pant, R. M. Pruss, and H. Gainer (1986) Calciumactivated proteolysis of neurofilament proteins in the squid giant neuron. J. Neurochem. 46:1573-1581.

Geisler, N., and K. Weber (1981) In vitro self-assembly of the 68,000 molecular weight component of the mammalian neurofilament triplet proteins into intermediate-sized filaments. J. Mol. Biol. 151: 565571.

Geisler, N., E. Kaufmann, S. Fischer, U. Plessmann, and K. Weber (1983) Neurofilament architecture combines structural principles of intermediate filaments with carboxy-terminal extensions increasing in size between triplet proteins. EMBO 2: 1295-1302.

Georges, E., S. Lefebre, and W. E. Mushynski (1986) Dephosphorylation of neurofilaments has no effect on reassembly of subunits. $J$. Neurochem. 47: 477-483.

Gilbert, D. S., B. J. Newby, and B. H. Anderton (1975) Neurofilament disguise, destruction and discipline. Nature 265: 586-589.

Glicksman, M. A., and M. Willard (1985) Differential expression of the three neurofilament polypeptides. Ann. NY Acad. Sci. 455: 479491.

Hirokawa, N., M. A. Glicksman, and M. B. Willard (1984) Organization of mammalian neurofilament polypeptides within the neuronal cytoskeleton. J. Cell Biol. 98: 1523-1536.

Hodge, A. J., and W. J. Adelman, Jr. (1980) The neuroplasmic network in Loligo and Hermissenda neurons. J. Ultrastruct. Res. 70: 220-241.

Hodge, A. J., and W. J. Adelman, Jr. (1983) The neuroplasmic lattice: Structural characteristics in vertebrate and invertebrate axons. In Structure and Function in Excitable Cells, D. C. Chang, I. Tasaki, W. J. Adelman, Jr., and H. R. Leuchtag, eds., pp. 75-112, Plenum, New York.

Holgatc, C. S., P. Jackson, P. N. Cowen, and C. C. Bird (1983) Im- 
munogold-silver staining: New method of immunostaining with enhanced sensitivity. J. Histochem. Cytochem. 31: 938-944.

Julien, J. P., and W. E. Mushynski (1981) A comparison of in vitro and in vivo-phosphorylated neurofilament polypeptides. J. Neurochem. 37: 1579-1585.

Julien, J. P., and W. E. Mushynski (1982) Multiple phosphorylation sites in mammalian neurofilament polypeptides. J. Biol. Chem. 257. 10467-10470.

Julien, J. P., and W. E. Mushynski (1983) The distribution of phosphorylated sites among identified proteolytic fragments of mammalian neurofilaments. J. Biol. Chem. 258: 4019-4025.

Lasek, R. J. (1974) Biochemistry of the squid giant axon. In A Guide to Laboratory Use of the Squid, Loligo pealei, J. M. Arnold, ed., p. 6974, Marine Biological Laboratory, Woods Hole, MA.

Lasek, R. J., and P. N. Hoffman (1976) The neuronal cytoskeleton, axonal transport and axonal growth. In Cell Motility, R. Goldman, T. Pollard and E. Rosenbaum, eds., pp. 1021-1049, Cold Spring Harbor Laboratory, New York.

Lasek, R. J., N. Krishnan, and I. R. Kaiserman (1979) Identification of the subunit proteins of $10-\mathrm{nm}$ neurofilaments isolated from axoplasm of squid and Myxicola giant axons. J. Cell Biol. 82: 336-346.

Leterrier, J., R. Liem, and M. Shelanski (1981) Differential phosphorylation of the 150,000 molecular weight component of neurofilaments by a cAMP-dependent, microlubule-dssuciated protein kinase. J. Cell Biol. 90: 755-760.

Liem, R., and S. B. Hutchinson (1982) Purification of the individual components of the neurofilament triplet: Filament assembly from the 70,000 dalton subunit. Biochemistry $21: 3221-3226$.

Metuzals, J. (1969) Configuration of a filamentous network in the axoplasm of the squid (Loligo peali L.) giant nerve fiber. J. Cell Biol. 43: 480-505

Metuzals, J., and C. S. Izzard (1969) Spatial patterns of threadlike elements in the axoplasm of the giant nerve fiber of the squid (Loligo pealii L.) as disclosed by differential interference microscopy and by electron microscopy. J. Cell Biol. 43: 456-479.

Metuzals, J., V. Montpetit, and D. F. Clapin (1981a) Organization of the neurofilamentous network. Cell Tissue Res. 214: 455-482.

Metuzals, J., I. Tasaki, S. Terakawa, and D. F. Clapin (1981b) Removal of the Schwann sheath from the giant nerve fiber of the squid: An electron-microscopic study of the axolemma and associated axoplasmic structures. Cell lissue Res. 221:1-15.

Metuzals, J., D. F. Clapin, and G. D. Chapman (1982) Axial and radial filamentous components of the neurofilamentous network. Cell Tissue Res. 223: 507-518.

Metuzals, J., D. F. Clapin, and I. Tasaki (1983a) The axolemmaectoplasm complex of squid giant axon. In Structure and Function in Excitable Cells, D. C. Chang, I. Tasaki, W. J. Adelman, Jr., and H. R. Leuchtag, eds., pp. 53-74, Plenum, New York.

Metuzals, J., A. J. Hodge, R. J. Lasek, and I. R. Kaiserman-Abramof (1983b) Neurofilamentous network and filamentous matrix preserved and isolated by different techniques from squid giant axon. Cell Tissue Res. 228: 415-432.

Moon, H., T. Wisniewski, P.Merz, J. DeMartin, and H. Wisniewski (1981) Partial purification of neurofilament subunits from bovine brains and studies on neurofilament assembly. J. Cell Biol. 89: 560567.

Neville, D. (1971) Molecular weight determination of protein-dodecyl sulfate complexes by gel electrophoresis in a discontinuous buffer system. J. Biol. Chem. 246: 6328-6334.

Oblinger, M. M., and B. Schick (1985) Post-translational processing of neurofilament proteins in mammalian sensory neurons occurs over a slow time course in vivo. J. Cell Biol. 101: 17a.

Pant, H. C., and H. Gainer (1980) Properties of a calcium-activated protease is squid axoplasm which selectively degrades neurofilament proteins. J. Neurobiol. 11: 1-12.

Pant, H. C., G. Shecket, H. Gainer, and R. J. Lasek (1978) Neurofilament protein is phosphorylated in the squid giant axon. J. Cell Biol. 78: R23-R27.

Pant, H. C., S. ' lerakawa, and H. Gainer (1979a) A calcium activated protease in squid axoplasm. J. Neurochem. 32: 99-102.

Pant, H. C., T. Yoshioka, I. Tasaki, and H. Gainer (1979b) Divalent cation dependent phosphorylation of proteins in squid axon. Brain Res. 162: 303-313.

Pant, H. C., P. F. Gallant, R. Gould, and H. Gainer (1982) Distribution of calcium-activated protease activity and endogenous substrates in the squid nervous system. J. Neurosci. 2: 1578-1587.
Pant, H. C., P. E. Gallant, and H. Gainer (1986) Characterization of a cyclic nucleotide- and calcium-independent neurofilament protein kinase activity in axoplasm from the squid giant axon. J. Biol. Chem. 261: 2968-2977.

Phillips, L. L., L. Autilio-Gambetti, and R. J. Lasek (1983) Bodian's silver stain reveals molecular variation in the evolution of neurofilament proteins. Brain Res. 278: 219-223.

Pierre, M., D. Toru-Delbauffe, J. Francon, J. Ostu, and F. Chantoux (1985) Characterization of a specific neurofilament protein kinase. Ann. NY Acad. Sci. 455: 808-811.

Pruss, R. M. (1985) Efficient detection of intermediate filament proteins using a panspecific monoclonal antibody: Anti IFA. J. Neuroimmunol. 8: 293-299.

Pruss, R. M., R. Mirsky, M. C. Raff, R. Thorp, A. J. Dowding, and B. H. Anderton (1981) All classes of intermediate filaments share a common antigenic determinant defined by a monoclonal antibody. Cell 27: 419-428.

Rice, R. V., P. F. Roslansky, N. Pasco, and S. M. Houghton (1980) Bridges between microtubules and neurofilaments visualized by stereo electron microscopy. J. Ultrastruct. Res. 71: 303-310.

Ridgway, R. L., and M. H. Chestnut (1984) Processing small tissue specimens in acrylic resins for ultramicrotomy: Improved handling and orientation. J. Electr. Microsc. Tech. 1: 205-206.

Roslansky, P. F., A. Cornell-Bell, R. V. Rice, and W. J. Adelman, Jr. (1980) Polypeptide composition of squid neurofilaments. Proc. Natl. Acad. Sci. USA 77: 404-408.

Roth, J. (1982) Applications of immunocolloids in light microscopy. Preparation of protein A-silver and protein A-gold complexes and their application for localization of single and multiple antigens in paraffin sections. J. Histochem. Cytochem. 30: 691-696.

Runge, M., M. R. El-Maghrabi, T. H. Claus, S. J. Pilkis, and R. C. Williams, Jr. (1981) A MAP-2-stimulated protein kinase activity associated with neurofilaments. Biochemistry 20: 175-180.

Schlaepfer, W., and U.-J. P. Zimmerman (1985) Calcium-activated proteolyses of intermediate filaments. Ann. NY Acad. Sci. 455: 552562.

Sharp, G. A., G. Shaw, and K. Weber (1982) Immunoelectronmicroscopical localization of the three neurofilament triplet protcins along neurofilaments of cultured dorsal root ganglion neurons. Exp. Cell Res. 137: 403-413.

Springall, D. R., G. W. Hacker, L. Grimelius, and J. M. Polak (1984) The potential of the immunogold-silver staining method for paraffin sections. Histochemistry 81: 603-608.

Sternberger, L. A., and N. H. Sternberger (1983) Monoclonal antibodies distinguish phosphorylated and nonphosphorylated forms of neurofilaments in situ. Proc. Natl. Acad. Sci. USA 80: 6126-6130.

Trojanski, J. Q., M. A. Obrocka, and V. M. Y. Lee (1985) Distribution of bovine neurofilament subunits in neurons and neuronal processes: Immunohistochemical studies of bovine cerebellum with subunit specific monoclonal antibodies. J. Histochem. Cytochem. 33: 557-563.

Tytell, M., W. D. Hill, R. D. Goldman, and R. V. Zackroff (1985) Regional distribution of squid neurofilament protcins. Ann. NY Acad. Sci. 455: 812-813.

Villegas, G. M., and R. Villegas (1984) Squid axon ultrastructure. In Current Topics in Membranes and Transport, Vol. 22, A. Kleinzeller and P. Baker, eds., pp. 3-37, Academic, New York.

Whitnall, M. H., H. Gainer, B. M. Cox, and C. J. Molineaux (1983) Dynorphin-A-(1-8) is contained within vasopressin neurosecretory vesicles in rat pituitary. Science 222: 1137-1139.

Willard, M., and C. Simon (1981) Antibody decoration of neurofilaments. J. Cell Biol. 89: 198-205.

Willard, M., and C. Simon (1983) Modulations of neurofilament axonal transport during the development of rabbit retinal ganglion cells. Cell 35: 551-559.

Young, J. Z. (1939) Fused neurons and synaptic contacts in the giant nerve fibers of ccphalopods. Phil. Trans. R. Soc. Lond. [Biol.] 229: $465-503$.

Zackroff, R. V., and R. D. Goldman (1980) In vitro reassembly of squid brain intermediate filaments (neurofilaments): Purification by assembly-disassembly. Science 208: 1152-1155.

Zackroff, R. V., W. W. Idler, P. M. Steinert, and R. D. Goldman (1982) In vitro reconstitution of intermediate filaments from mammalian neurofilament triplet peptides. Proc. Natl. Acad. Sci. USA 79: 754757 . 